\title{
Emergy Analysis for Transportation Fuels Produced from Corn Stover in China
}

Changqi Liu ${ }^{1,2}$, Yaji Huang ${ }^{1 *}$, Xinye Wang $^{1}$, Yang Tai ${ }^{1}$, Lingqin Liu ${ }^{1}$, Chenggong

$$
\begin{aligned}
& \qquad \operatorname{Sun}^{2}, \mathrm{Hao} \mathrm{Liu}^{2 *} \\
& { }^{1} \text { Key Laboratory of Energy Thermal Conversion and Control of Ministry of } \\
& \text { Education, School of Energy and Environment, Southeast University, Nanjing } \\
& \text { 210096, China }
\end{aligned}
$$

${ }^{2}$ Faculty of Engineering, University of Nottingham, University Park, Nottingham

$$
\text { NG7 2RD, UK }
$$

E-mail:heyyjseu@qq.com (Y. Huang); liu.hao@nottingham.ac.uk (H.Liu)

ABSTRACT: In order to provide more useful information for the decision makers in China to implement sustainable energy policies and to identify which region in China is most suitable to build the biofuel production plants for fast pyrolysis and hydroprocessing of corn stover, the present study has evaluated the production efficiency and sustainability of large-scale transportation fuel production via fast pyrolysis and hydroprocessing of corn stover in China using Emergy analysis approach. Both the hydrogen production scenario (i.e. oil hydroprocessing using the hydrogen derived from bio-oil reforming) and the hydrogen purchase scenario (i.e. oil hydroprocessing using the hydrogen purchased from market) in three regions of China (Northeast China Plain (NECP), North China Plain (NCP) and Shaanxi Province (SXP)) have been investigated. The results have shown that maize production, and fast pyrolysis and hydroprocessing are the two biggest emergy input stages of the biofuel production system. The comparison of the emergy indices of all of the six cases 
investigated indicates that the hydrogen purchase scenario in NCP is the best biofuel production case due to its second best sustainability and the second highest production efficiency. In comparison to bioethanol from cassava chips and wheat and biodiesel from jatropha curcas L, the hydrogen purchase scenario in NCP is also the most sustainable plan for a biofuel production plant in China. As water, fertilizer and hydrogen are the three biggest emergy inputs in this case, improvements on the water management, fertilizer management and hydrogen production technology have been discussed. In order to further increase the efficiency and sustainability of the hydrogen purchase scenario in NCP, some of the necessary efforts required from the relevant sectors have also been put forward based on the results of the emergy analysis.

\section{Keywords: Emergy analysis; corn stover; fast pyrolysis and hydroprocessing;}

\section{sustainability; biofuel production}

\section{Introduction}

With the rapid fossil fuel depletion, energy shortage and growing concerns on environmental pollution all over the world, biofuels are playing an increasingly important role as a renewable substitute for fossil-based fuels for transportation (Li et al., 2015; Pereira and Ortega, 2010). There are many feasible pathways including various thermochemical (e.g. gasification) and biochemical processes (e.g. fermentation) to derive transportation fuels from biomass. Compared with gasification and biochemical processes, biomass-to-liquid transportation fuel production via fast pyrolysis followed by hydroprocessing has some advantages including its commercial feasibility in the near future, the high level of technology development and the low 
capital and operating cost (Anex et al., 2010). Biomass fast pyrolysis and bio-oil upgrading have been intensively researched and developed over the past decade, and were recently reviewed by Bridgewater (Bridgwater, 2012) and Elliott (Elliott, 2013).

The first generation liquid biofuels, which are derived from food crops such as cereals, sugar crops and oil seeds, have already become mature commercial market products. However, they have many issues such as compromising food security, high production and processing cost and large life cycle $\mathrm{CO}_{2}$ emissions when considering land-use change (Sims et al., 2010; Liang et al., 2013).The second generation liquid biofuels from non-food biomass feedstocks such as cereal straw, sugarcane bagasse, and forest residues are considered much more sustainable and are being produced at a continuously growing rate as a result of the supports from governments around the world. Corn stover is a valuable biomass with considerable potential for producing the second generation biofuels in most countries with maize production. A number of investigations have already focused on the techno-economic and environmental assessment of biofuel production from corn stover (Anex et al., 2010; Saini et al., 2015; Han et al., 2013; Zhang et al., 2014; Kauffman et al., 2011). China is one of the largest maize production countries and produces about 154Mt/year corn stover (Wang et al., 2013) which represents an enormous potential for the production of transportation biofuels. Therefore, corn stover is considered as one of the best biomass feedstocks for the second generation biofuel production in China.

When planning a biofuel supply network, the decision-makers should consider not only the economic efficiency and environmental performance of the industrial process 
but also its long term sustainability. The evaluation of sustainability can be used to provide insight for the development of an industrial-scale production system that will not severely or irreversibly damage the nature environment. Multi-criteria decisionmaking methodology investigating economic performances, environmental issues and social concerns was often used for evaluating sustainability of industrial systems in previous literature (Ren et al., 2015b; Ren et al., 2016a; Ren et al., 2016b; Yang and Chen, 2014). However, over the recent years, the emergy methodology has been proved to be the most direct and apparent method to represent the essence of sustainability of an industrial system, and be able to estimate all flows of energy, materials, information, services, and currencies on the common basis of "solar energy" (Yang et al., 2010; Baralet al., 2016; Chen et al., 2016). In addition, emergy analysis can identify the balance between the socio-economic development and natural environment and can make comparisons and comprehensive analysis of all flows from ecosystems and industrial systems (Ju and Chen, 2011; Zhang and Chen, 2017). A number of previous studies had described in detail the emergy analysis of the first generation liquid biofuels and the results had indicated that the biofuels generated from soybean (Ren et al., 2013; Cavalett and Ortega, 2010; Ren et al., 2015a), rapeseed (Ren et al., 2013; Ren et al., 2015a), sunflower (Ren et al., 2013; Spinelli et al., 2012; Spinelli et al., 2013; Ren et al., 2015a) and rice (Lu et al., 2012) did not have good sustainability in long term. So far, few have used emergy analysis to evaluate the second generation liquid biofuels produced by fast pyrolysis and hydroprocessing and hence the sustainability of these biofuels has not been fully explored. 
The aim of this study is to investigate the feasibility and sustainability of the transportation fuel production system via fast pyrolysis followed by hydroprocessing from the maize field residue(corn stover) in three main maize production regions (Northeast China Plain (NECP), North China Plain (NCP) and Shaanxi Province (SXP))of China. The region which is most suitable for the biofuel production from corn stover among the three studied regions in China has been identified using the emergy indices. Some efficacious strategic measures have been put forward to promote the sustainable development of transportation fuel production via fast pyrolysis followed by hydroprocessing. The results and suggestions of the present study can provide some useful information for government to formulate energy policies that can promote largescale transportation biofuel production using corn stover in China.

\section{Material and method}

In this section, how to apply emergy methodology to the system of biofuel production via fast pyrolysis followed by hydroprocessing is first introduced and then the six cases to be analyzed are identified and selected and finally the three main stages of the biofuel production (maize production, corn stover collection and transportation, fast pyrolysis and hydroprocessing) in the six cases are described.

\subsection{Emergy analysis}

Emergy methodology was introduced to provide a method of assessing different systems by Odum H. T. (Odum, 1996) and is usually used to evaluate the sustainability of industrial systems (Yang et al., 2010; Baral et al., 2016; Chen et al., 2016; Park et al., 2016).The biofuel production system in this study has three main stages: maize 
111 production, corn stover collection and transportation, fast pyrolysis and

112 hydroprocessing. According to the procedure of emergy analysis, the first step is to

113 define the boundaries of the system, describe and create an emergy flows' diagram as

114 shown in Fig. 1, then, to classify and account for all energy inputs and outputs to create

115 the table of emergy analysis. All inputs and outputs are in the units of J, $\mathrm{kg}$ or \$. Emergy

116 flows are classified according to their sources as renewable environmental resources

$117(\mathrm{R})$, non-renewable environmental resources $(\mathrm{N})$, organic assistant energy $\left(\mathrm{F}_{\mathrm{R}}\right)$, and

118 inorganic assistant energy $\left(\mathrm{F}_{\mathrm{N}}\right)$. Then, the original data of all inputs are converted to

119 emergy by multiplying relevant transformities (Odum, 1996). The emergy yield (Y)

120 represents the output of the total emergy produced by the given system. Finally, the

121 relevant emergy indices are calculated by using all emergy flows to evaluate the overall

122 sustainability of the process and used for the comparison with other technologies (Cruz

123 and Nascimento, 2012). Emergy indices related to the sustainability metrics, selected

124 to evaluate the biofuel production from corn stover, are presented in Table 1. 


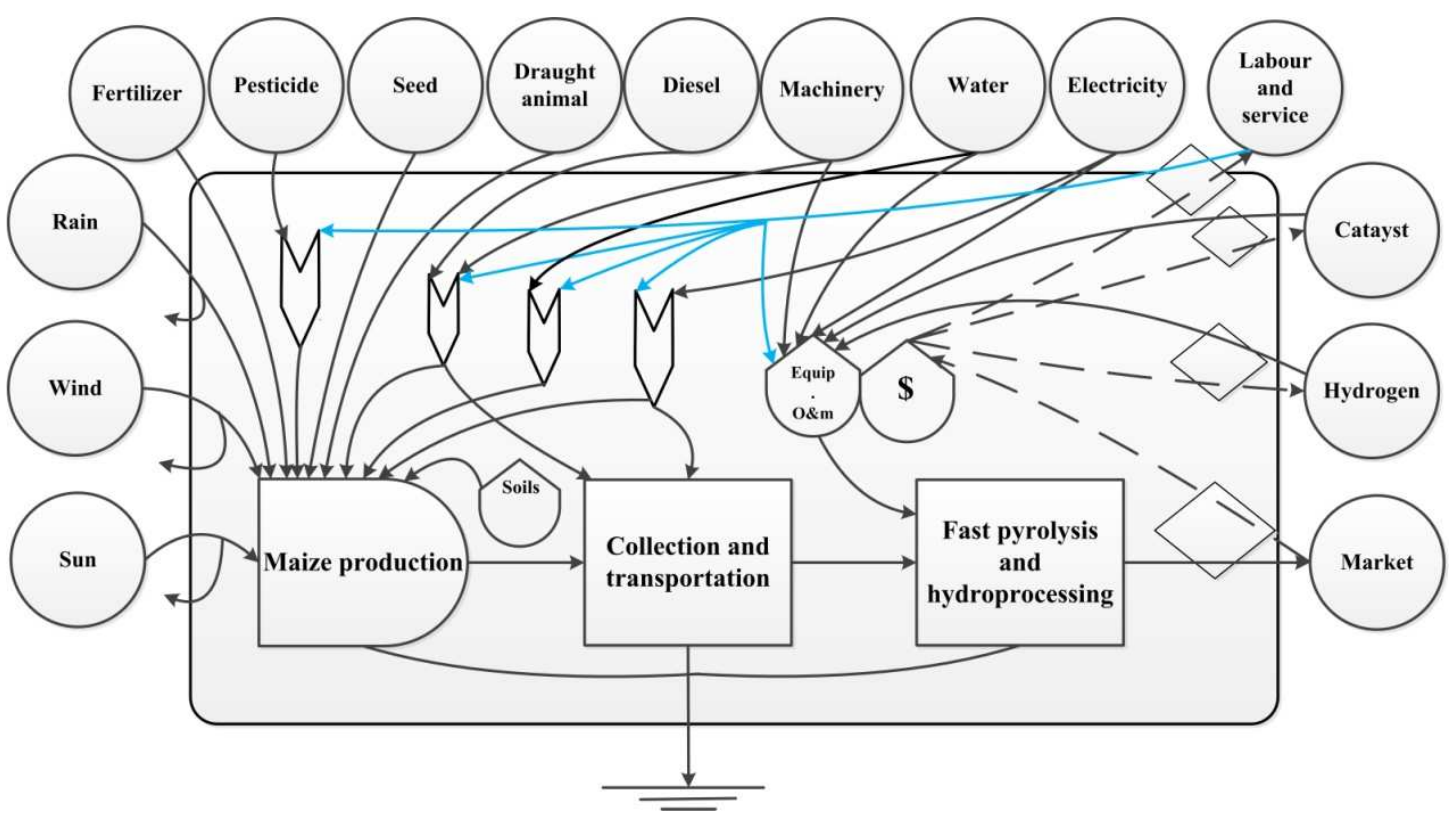

Fig.1 Emergy flow diagram of bio-fuels form corn stover

Table 1 Emergy indices used for the analysis of the biofuel production system from corn stover

\begin{tabular}{|c|c|c|c|}
\hline Index & Formula & $\begin{array}{l}\text { References using the } \\
\text { metrics }\end{array}$ & Description \\
\hline $\begin{array}{l}\text { Total emergy } \\
\text { use(U) }\end{array}$ & $\mathrm{U}=\mathrm{R}+\mathrm{N}+\mathrm{F}_{\mathrm{R}}+\mathrm{F}_{\mathrm{N}}$ & $\begin{array}{l}\text { Zhang et al., 2014; } \\
\text { Takahashi and Ortega, } \\
\text { 2010; Cruz and } \\
\text { Nascimento, } 2012\end{array}$ & $\begin{array}{l}\text { The total emergy is used to support the whole production } \\
\text { system }\end{array}$ \\
\hline $\begin{array}{c}\text { Transformity(Tr } \\
\text { ) }\end{array}$ & $\operatorname{Tr}=\mathrm{U} /$ output & $\begin{array}{c}\text { Zhang et al., } \\
\text { 2014;Takahashi and } \\
\text { Ortega, 2010; Cruz and } \\
\text { Nascimento, } 2012\end{array}$ & $\begin{array}{l}\text { It measures how much emergy it takes to generate one } \\
\qquad \text { unit of output }\end{array}$ \\
\hline $\begin{array}{l}\text { Emergy yield } \\
\text { ratio(EYR) }\end{array}$ & $\mathrm{EYR}=\mathrm{U} /\left(\mathrm{F}_{\mathrm{R}}+\mathrm{F}_{\mathrm{N}}\right)$ & $\begin{array}{l}\text { Tao et al., 2013; Zhang } \\
\text { et al., 2014; Takahashi } \\
\text { and Ortega, } 2010\end{array}$ & $\begin{array}{l}\text { It is a measure of the ability of a production system to } \\
\text { explore and make locally nature resource by investing } \\
\text { outside resource }\end{array}$ \\
\hline $\begin{array}{l}\text { Environmental } \\
\text { loading } \\
\text { ratio(ELR) }\end{array}$ & $\mathrm{ELR}=\left(\mathrm{N}+\mathrm{F}_{\mathrm{N}}\right) /(\mathrm{R}+\mathrm{F})$ & $\begin{array}{l}\text { Tao et al., 2013; Zhang } \\
\text { et al., 2014; Liang et al., } \\
2013\end{array}$ & $\begin{array}{l}\text { The ratio of all nonrenewable resource to renewable } \\
\text { resource indicating the pressure that the production } \\
\text { system places on the local environment }\end{array}$ \\
\hline $\begin{array}{l}\text { Emergy } \\
\text { sustainability } \\
\text { index(ESI) }\end{array}$ & ESI=EYR/ELR & $\begin{array}{l}\text { Zhang et al., 2014; Cruz } \\
\text { and Nascimento, 2012; } \\
\text { Liang et al., } 2016\end{array}$ & $\begin{array}{l}\text { It is a comprehensive measure of the yield efficiency and } \\
\text { environmental loading, indicating the sustainability of the } \\
\text { system }\end{array}$ \\
\hline $\begin{array}{l}\text { Emergy/dollar } \\
\text { ratio(EDR) }\end{array}$ & $\mathrm{EDR}=$ emergy/GNP & $\begin{array}{l}\text { Tao et al., 2013; Yang et } \\
\text { al., } 2010\end{array}$ & $\begin{array}{l}\text { The total emergy use divided by GNP in a specific region } \\
\text { and specific year, can be used to value the purchasing } \\
\text { power of the money }\end{array}$ \\
\hline
\end{tabular}




\subsection{Identification of the cases for the emergy analysis}

Six cases to be analyzed have been identified and selected for the emergy analysis and are shown in Table 2.Two kinds of biofuel production plants in each region are considered, i.e. the hydrogen production scenario case (Case 1 - NECP, Case 3 - NCP and Case 5 - SXP) and the hydrogen purchase scenario case (Case 2 - NECP, Case 4 NCP and Case 6 - SXP). Each case contains three stages: maize production, corn stover collection and transportation, and fast pyrolysis and hydroprocessing. The chain of the biofuel production can be described as follows: corn stover is first collected after maize harvest and then is transported to a biofuel production plant, where it is used to produce biofuels via the fast pyrolysis and hydroprocessing process. The stages of maize production and corn stover collection and transportation are region-dependent whereas the stage of fast pyrolysis and hydroprossing which can be either the hydrogen production scenario or the hydrogen purchase scenario is assumed to be the same for all three regions. The data of maize production are specific to the three different regions (NECP, NCP and SXP) in China with the details shown in Section 2.3. The stage of corn stover collection and transportation is assumed to be the same for both cases of each region with further details given in Section 2.4. The biofuel production plants have been modeled to consume the same amount of corn stover feedstock (2000 metric tons per day) per year in all cases (Wright et al., 2010). The hydrogen production scenario cases (Case 1, Case 3 and Case 5) involve large-scale pyrolysis with oil hydroprocessing using hydrogen derived from bio-oil reforming, whereas the hydrogen purchase scenario cases (Case 2, Case 4 and Case 6) use off-site generation of hydrogen 
for oil hydroprocessing. The details of these two scenarios are further described in Section 2.5.

\subsection{Maize production}

Table 2 Six cases of biofuels production via fast pyrolysis and hydroprossingof corn stover

\begin{tabular}{cccc}
\hline & Stage 1 & Stage 2 & Stage 3 \\
\hline Case 1 & Maize production in NECP & Collectionand transportation & Hydrogen production scenario \\
Case 2 & Maize production in NECP & Collection and transportation & Hydrogen purchasescenario \\
Case 3 & Maize production in NCP & Collection and transportation & Hydrogen production scenario \\
Case 4 & Maize production in NCP & Collection and transportation & Hydrogen purchasescenario \\
Case 5 & Maize production in SXP & Collection and transportation & Hydrogen production scenario \\
Case 6 & Maize production in SXP & Collection and transportation & Hydrogen purchasescenario \\
\hline
\end{tabular}

NECP, NCP and SXP are the three main regions for maize production in China. All input data and maize yields for the maize production systems in NECP, NCP and SXP come from Zhang et al. (Zhang et al., 2005), Li et al.(Li and Yan, 2012) and Wang (Wang,2011), respectively. Each biofuel plant is assumed to process 2000 dry metric ton/day corn stover using common thermochemical conversion facilities. The online time of the plant is assumed to be 350 days/year (Wright et al., 2010). Therefore, the plant needs 700000t dry corn stover every year. Based on the maize yields and the field residue indices of the three regions, the land areas of maize production are calculated, then, all of the total input data related to sunlight, rain, wind, net top soil loss, machinery, electricity, diesel, fertilizer, pesticide, irrigation water, labor, seeds, draught animal in three regions can be calculated as shown in Table 3. The emergy dollar ratio (EDR) 
169 (Table 1) used in this study is taken as 5.87E+12 sej/\$according to Yang et al., 2010. 
Table 3Emergy analysis of stage of maize production

\begin{tabular}{|c|c|c|c|c|c|c|c|c|c|c|c|c|c|c|}
\hline & & & \multicolumn{4}{|c|}{$\begin{array}{l}\text { Northeast China Plain (NECP) } \\
\qquad(5.95 \mathrm{E}+04 \mathrm{ha})\end{array}$} & \multicolumn{4}{|c|}{$\begin{array}{l}\text { North China Plain (NCP) } \\
\qquad(9.42 \mathrm{E}+04 \mathrm{ha})\end{array}$} & \multicolumn{4}{|c|}{$\begin{array}{c}\text { Shaanxi province (SXP) } \\
\quad(1.53 \mathrm{E}+05 \mathrm{ha})\end{array}$} \\
\hline & \multirow[t]{2}{*}{ Item $(\mathrm{J})$} & \multirow[t]{2}{*}{ Class } & \multirow{2}{*}{$\begin{array}{c}\text { Transformity }^{\mathrm{a}} \\
\text { (sej/unit) }\end{array}$} & \multirow[t]{2}{*}{ References } & \multicolumn{2}{|c|}{ Emergy（sej） } & \multirow{2}{*}{$\begin{array}{l}\text { Transformity }^{\mathrm{a}} \\
\text { (sej/unit) }\end{array}$} & \multirow[t]{2}{*}{ References } & \multicolumn{2}{|c|}{ Emergy (sej) } & \multirow{2}{*}{$\begin{array}{c}\text { Transformity }^{\mathrm{a}} \\
\text { (sej/unit) }\end{array}$} & \multirow[t]{2}{*}{ References } & \multicolumn{2}{|c|}{ Emergy (sej) } \\
\hline & & & & & Case 1 & Case 2 & & & Case 3 & Case 4 & & & Case 5 & Case 6 \\
\hline 1 & Sunlight(J) & $\mathrm{R}$ & $1.00 \mathrm{E}+00$ & $\begin{array}{c}\text { Zhang et al., } \\
2005\end{array}$ & $1.74 \mathrm{E}+18$ & $1.74 \mathrm{E}+18$ & $1.00 \mathrm{E}+00$ & $\begin{array}{l}\text { Li and Yan, } \\
2012\end{array}$ & $4.68 \mathrm{E}+18$ & $4.68 \mathrm{E}+18$ & $1.00 \mathrm{E}+00$ & Wang, 2011 & $5.84 \mathrm{E}+19$ & $5.84 \mathrm{E}+19$ \\
\hline 2 & $\begin{array}{c}\text { Rain }(\text { chemical } \\
\text { potential })(J)\end{array}$ & $\mathrm{R}$ & $1.54 \mathrm{E}+04$ & $\begin{array}{l}\text { Zhang et al., } \\
2005\end{array}$ & $2.04 \mathrm{E}+19$ & $2.04 \mathrm{E}+19$ & $1.54 \mathrm{E}+04$ & $\begin{array}{l}\text { Li and Yan, } \\
2012\end{array}$ & $1.39 \mathrm{E}+19$ & $1.39 \mathrm{E}+19$ & $1.54 \mathrm{E}+04$ & Wang, 2011 & $2.54 \mathrm{E}+20$ & $2.54 \mathrm{E}+20$ \\
\hline 3 & $\begin{array}{l}\text { Rain(potential } \\
\text { energy)(J) }\end{array}$ & $\mathrm{R}$ & $8.89 \mathrm{E}+03$ & $\begin{array}{l}\text { Zhang et al., } \\
2005\end{array}$ & $2.04 \mathrm{E}+19$ & $2.04 \mathrm{E}+19$ & $1.82 \mathrm{E}+04$ & $\begin{array}{l}\text { Li and Yan, } \\
2012\end{array}$ & $6.25 \mathrm{E}+19$ & $6.25 \mathrm{E}+19$ & $8.89 \mathrm{E}+03$ & Wang, 2011 & $4.88 \mathrm{E}+20$ & $4.88 \mathrm{E}+20$ \\
\hline 4 & Wind $(J)$ & $\mathrm{R}$ & $1.50 \mathrm{E}+03$ & $\begin{array}{l}\text { Li and Yan, } \\
2012\end{array}$ & $9.51 \mathrm{E}+18$ & $9.51 \mathrm{E}+18$ & $1.50 \mathrm{E}+03$ & $\begin{array}{l}\text { Li and Yan, } \\
2012\end{array}$ & $3.07 \mathrm{E}+19$ & $3.07 \mathrm{E}+19$ & $1.50 \mathrm{E}+03$ & Wang, 2011 & $3.36 \mathrm{E}+18$ & $3.36 \mathrm{E}+18$ \\
\hline 5 & $\begin{array}{l}\text { Net top soil } \\
\operatorname{loss}(\mathrm{J})\end{array}$ & $\mathrm{N}$ & $6.25 \mathrm{E}+04$ & $\begin{array}{l}\text { Zhang et al., } \\
2005\end{array}$ & $3.36 \mathrm{E}+18$ & $3.36 \mathrm{E}+18$ & $6.25 \mathrm{E}+04$ & $\begin{array}{l}\text { Li and Yan, } \\
2012\end{array}$ & $3.17 \mathrm{E}+19$ & $3.17 \mathrm{E}+19$ & $6.25 \mathrm{E}+04$ & Wang, 2011 & $1.26 \mathrm{E}+20$ & $1.26 \mathrm{E}+20$ \\
\hline 6 & $\begin{array}{l}\text { Machinery } \\
\quad(\mathrm{kg})\end{array}$ & $\mathrm{F}_{\mathrm{N}}$ & $6.70 \mathrm{E}+09$ & $\begin{array}{l}\text { Zhang et al., } \\
2005\end{array}$ & $4.38 \mathrm{E}+18$ & $4.38 \mathrm{E}+18$ & $6.70 \mathrm{E}+09$ & $\begin{array}{l}\text { Li and Yan, } \\
2012\end{array}$ & $1.19 \mathrm{E}+19$ & $1.19 \mathrm{E}+19$ & $6.70 \mathrm{E}+09$ & Wang, 2011 & $4.25 \mathrm{E}+19$ & $4.25 \mathrm{E}+19$ \\
\hline 7 & Electricity $(J)$ & $\mathrm{F}_{\mathrm{N}}$ & $1.70 \mathrm{E}+05$ & $\begin{array}{l}\text { Zhang et al., } \\
2005\end{array}$ & $0.00 \mathrm{E}+00$ & $0.00 \mathrm{E}+00$ & $1.70 \mathrm{E}+05$ & $\begin{array}{l}\text { Li and Yan, } \\
2012\end{array}$ & $2.46 \mathrm{E}+18$ & $2.46 \mathrm{E}+18$ & $0.00 \mathrm{E}+00$ & Wang, 2011 & $0.00 \mathrm{E}+00$ & $0.00 \mathrm{E}+00$ \\
\hline 8 & Diesel fuel(J) & $\mathrm{F}_{\mathrm{N}}$ & $6.60 \mathrm{E}+04$ & $\begin{array}{l}\text { Zhang et al., } \\
2005\end{array}$ & $7.51 \mathrm{E}+18$ & $7.51 \mathrm{E}+18$ & $6.60 \mathrm{E}+04$ & $\begin{array}{l}\text { Li and Yan, } \\
2012\end{array}$ & $1.83 \mathrm{E}+19$ & $1.83 \mathrm{E}+19$ & $6.60 \mathrm{E}+04$ & Wang, 2011 & $6.47 \mathrm{E}+19$ & $6.47 \mathrm{E}+19$ \\
\hline
\end{tabular}




\begin{tabular}{|c|c|c|c|c|c|c|c|c|c|c|c|c|c|c|}
\hline 9 & $N(g)$ & $\mathrm{F}_{\mathrm{N}}$ & $4.62 \mathrm{E}+09$ & $\begin{array}{c}\text { Zhang et al., } \\
2005\end{array}$ & $5.07 \mathrm{E}+19$ & $5.07 \mathrm{E}+19$ & $2.30 \mathrm{E}+09$ & $\begin{array}{c}\text { Li and Yan, } \\
2012\end{array}$ & $\begin{array}{c}1.17 \mathrm{E}+20 \\
\text { b }\end{array}$ & $1.17 \mathrm{E}+20^{b}$ & $4.62 \mathrm{E}+09$ & Wang, 2011 & $5.85 \mathrm{E}+19$ & $5.85 \mathrm{E}+19$ \\
\hline 10 & $\mathrm{P}(\mathrm{g})$ & $\mathrm{F}_{\mathrm{N}}$ & $1.78 \mathrm{E}+10$ & $\begin{array}{l}\text { Zhang et al., } \\
2005\end{array}$ & $9.69 \mathrm{E}+19$ & $9.69 \mathrm{E}+19$ & - & & - & - & $1.78 \mathrm{E}+10$ & Wang, 2011 & $5.89 \mathrm{E}+19$ & $5.89 \mathrm{E}+19$ \\
\hline 11 & $\mathrm{~K}(\mathrm{~g})$ & $\mathrm{F}_{\mathrm{N}}$ & $2.96 \mathrm{E}+09$ & $\begin{array}{c}\text { Zhang et al., } \\
2005\end{array}$ & $8.19 \mathrm{E}+18$ & $8.19 \mathrm{E}+18$ & - & & - & - & $2.96 \mathrm{E}+09$ & Wang, 2011 & $2.24 \mathrm{E}+19$ & $2.24 \mathrm{E}+19$ \\
\hline 12 & $\begin{array}{c}\text { Manure(organic } \\
\text { fertilizer)(g) }\end{array}$ & $\mathrm{F}_{\mathrm{R}}$ & $2.70 \mathrm{E}+06$ & $\begin{array}{c}\text { Zhang et al., } \\
2005\end{array}$ & $1.51 \mathrm{E}+18$ & $1.51 \mathrm{E}+18$ & - & & - & - & $2.80 \mathrm{E}+09$ & Wang, 2011 & $2.54 \mathrm{E}+20$ & $2.54 \mathrm{E}+20$ \\
\hline 13 & $\begin{array}{l}\text { Compound } \\
\text { fertilizer(g) }\end{array}$ & $\mathrm{F}_{\mathrm{N}}$ & $2.80 \mathrm{E}+09$ & $\begin{array}{c}\text { Zhang et al., } \\
2005\end{array}$ & $1.12 \mathrm{E}+19$ & $1.12 \mathrm{E}+19$ & - & & - & - & $2.80 \mathrm{E}+09$ & Wang, 2011 & $1.33 \mathrm{E}+19$ & $1.33 \mathrm{E}+19$ \\
\hline 14 & Pesticide(g) & $\mathrm{F}_{\mathrm{N}}$ & $1.62 \mathrm{E}+09$ & $\begin{array}{c}\text { Zhang et al., } \\
2005\end{array}$ & $1.29 \mathrm{E}+18$ & $1.29 \mathrm{E}+18$ & $1.48 \mathrm{E}+10$ & $\begin{array}{c}\text { Li and Yan, } \\
2012\end{array}$ & $6.32 \mathrm{E}+18$ & $6.32 \mathrm{E}+18$ & $1.62 \mathrm{E}+09$ & Wang, 2011 & $1.08 \mathrm{E}+19$ & $1.08 \mathrm{E}+19$ \\
\hline 15 & $\begin{array}{l}\text { Irrigation } \\
\text { water }\left(\mathrm{m}^{3}\right)\end{array}$ & $F_{R}$ & - & - & - & - & $1.56 \mathrm{E}+12$ & $\begin{array}{c}\text { Li and Yan, } \\
2012\end{array}$ & $5.19 \mathrm{E}+20$ & $5.19 \mathrm{E}+20$ & - & - & - & - \\
\hline 16 & Labor(h) & $\mathrm{F}_{\mathrm{R}}$ & $3.80 \mathrm{E}+05$ & $\begin{array}{l}\text { Zhang et al., } \\
2005\end{array}$ & $1.65 \mathrm{E}+19$ & $1.65 \mathrm{E}+19$ & $1.12 \mathrm{E}+12$ & $\begin{array}{c}\text { Li and Yan, } \\
2012\end{array}$ & $\begin{array}{c}3.88 \mathrm{E}+19 \\
\mathrm{c}\end{array}$ & $3.88 \mathrm{E}+19^{\mathrm{c}}$ & $3.80 \mathrm{E}+05$ & Wang, 2011 & $5.01 \mathrm{E}+21$ & $5.01 \mathrm{E}+21$ \\
\hline 17 & $\begin{array}{l}\text { Draught } \\
\operatorname{animal}(\mathrm{J})\end{array}$ & $\mathrm{F}_{\mathrm{R}}$ & $1.46 \mathrm{E}+05$ & $\begin{array}{c}\text { Zhang et al., } \\
2005\end{array}$ & $1.68 \mathrm{E}+18$ & $1.68 \mathrm{E}+18$ & - & & - & - & - & & - & - \\
\hline 18 & Seeds $(J)$ & $\mathrm{F}_{\mathrm{R}}$ & $2.00 \mathrm{E}+05$ & $\begin{array}{l}\text { Zhang et al., } \\
2005\end{array}$ & $1.33 \mathrm{E}+19$ & $1.33 \mathrm{E}+19$ & $1.96 \mathrm{E}+10$ & $\begin{array}{c}\text { Li and Yan, } \\
2012\end{array}$ & $\begin{array}{c}2.73 E+19 \\
d\end{array}$ & $2.73 \mathrm{E}+19^{\mathrm{d}}$ & $2.00 \mathrm{E}+05$ & $\begin{array}{l}\text { Zhang et } \\
\text { al., } 2005\end{array}$ & $1.70 \mathrm{E}+19$ & $1.70 \mathrm{E}+19$ \\
\hline
\end{tabular}

171 a. The emergy baseline was upgraded to the value of 15.2E+24 seJ/year (Brown and Ulgiati, 2010). However, alltransformities in this study were

172 calculated based on the emergy baseline value of the 9.44E+24seJ/year (Odum, 1996). This is due to easy comparison of the results in other study

173 using the same emergy baseline.

174 b.This item includes nitrogen, phosphorus, potash fertilize and compound fertilize. Unit of this item is J not $g$.

175 c, d.Seed and labor, considering the economic value, are taken as purchased resource. Unit of this item is J not g. 
177

178

179

180

181

182

183

184

185

186

187

188

189

190

191

192

193

194

195

196

197

198

\subsection{Corn stover collection and transportation}

The baling pattern described by Cao et al. (2012) is adopted as the crop residue collection method. The equipment used for the residue collection consists of stover pick-up machine, baler, shredder, forklift truck and scraper. All inputs of collection including machinery, electricity, diesel and labor are presented in Table 3 (Liuet al., 2011). The formula used to calculate the average haulage distance of corn stover is described by equation (1) (Kauffman et al., 2011):

$$
\mathrm{D}=0.4789 \sqrt{\frac{\mathrm{S}}{100 \mathrm{Yd}}}(1)
$$

where $\mathrm{D}$, in $\mathrm{km}$, is the average haulage distance; $\mathrm{S}$, in tons, is the amount of annual feedstock input; $\mathrm{Y}$, in tons per hectare, is the biomass yield; $\mathrm{d}$ is the crop density and is assumed to be uniform and constant (0.20).

The average haulage distance in three regions (NECP, NCP, SXP) is calculated to be $26.1 \mathrm{~km}, 33.2 \mathrm{~km}$ and $41.9 \mathrm{~km}$, respectively. Using the truck transportation energy density of $1.12 \mathrm{MJ} /\left(\mathrm{t}^{*} \mathrm{~km}\right)$ (Yang, 2011), the total diesel consumed by trucks in each biofuel plant of the three regions is found to be $2.04 \mathrm{E}+13 \mathrm{~J}, 2.60 \mathrm{E}+13 \mathrm{~J}, 3.28$ E+13J,respectively.The driver service is not considered here. The emergy inputs of transportation in three regions are included in Table 4. 


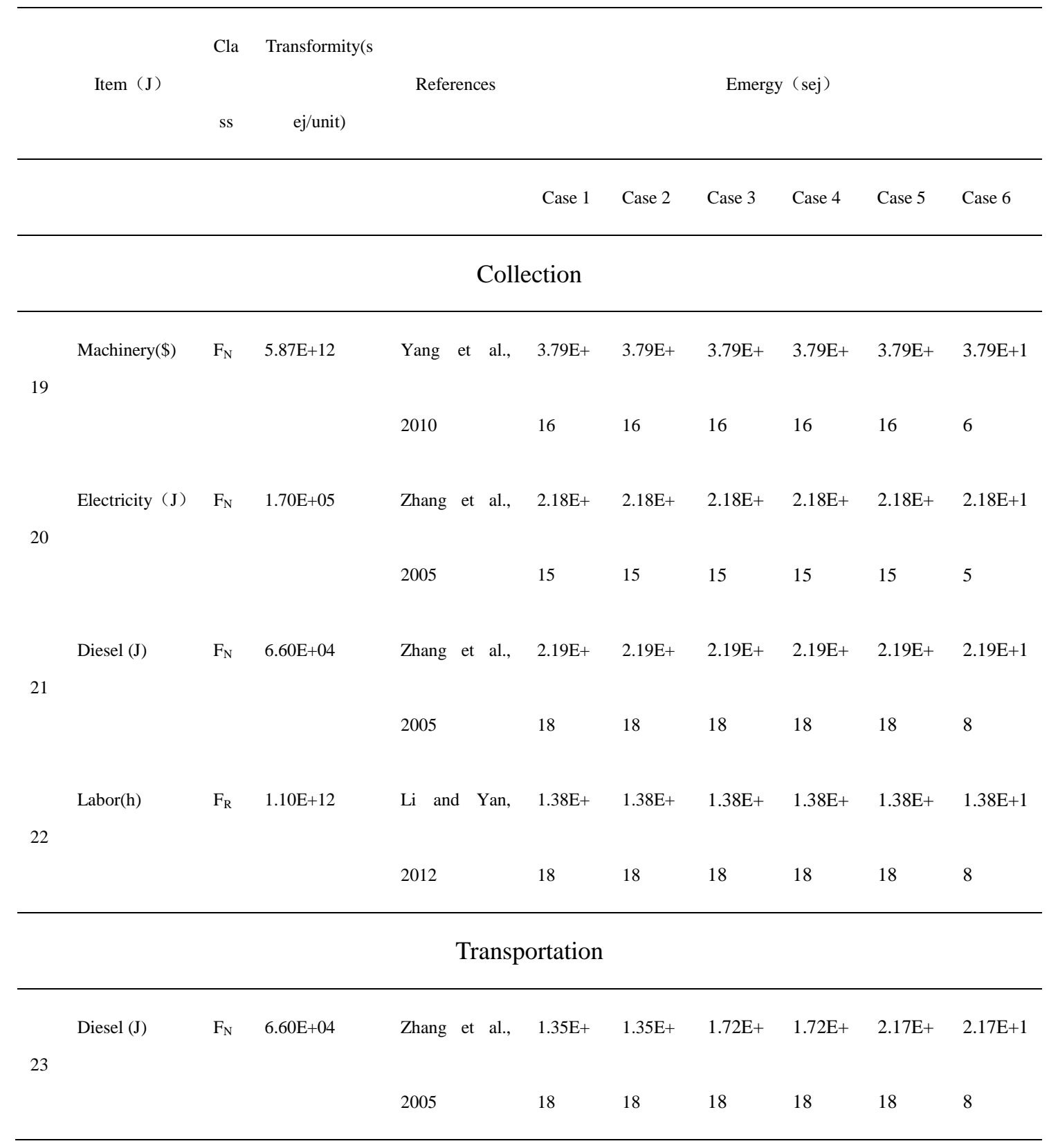

\subsection{Fast pyrolysis andhydroprocessing}

Fast pyrolysis is a thermochemical pathway that can be used to transform biomass

203 stover is subjected to fast pyrolysis followed by hydroprocessing based on the model

204 built by Wright et al (Wright et al., 2010).Figure 2 shows the process diagrams of the 205 hydrogen production scenario and the hydrogen purchase scenario. Each process 
consists of eight steps: chopping/grinding, drying, pyrolysis, cleanup, oil collection, storage, combustion, hydroprocessing. The detailed process can be described as follows: corn stover with $25 \%$ moisture content is first dried to $7 \%$ moisture content by the dryer and ground to 3-mm-diameter by the chopper and grinder and then it is fed to a fluidized bed pyrolysis reactor. The pyrolysis reactor operates at $480^{\circ} \mathrm{C}$ and atmospheric pressure. In the pyrolysis process, vapors exiting the pyrolysis reactor, solids containing mostly bio-char particles are removed by cyclones and sent to the combustor to provide heat for the drying and fast pyrolysis. Excess solids consisting of char are considered as a co-product. While the vapors from the cyclone outlet are condensed in the heat exchangers and the condensable gases turn into liquid bio-oil, which can be stored in the storage tanks prior to upgrading. In order to provide heat for fast pyrolysis, noncondensable gases from the heat exchanger outlet are sent to the pyrolysis reactor for combustion. Similar to the method used in the petroleum industry, the upgrading process is hydrotreating and hydrocracking. The hydrogen production scenario uses more equipment including the separator, reformer and pressure swing adsorption as shown in Fig 2 (a) to generate the required hydrogen, while the hydrogen purchase scenario uses the merchant hydrogen for upgrading (Fig.2 (b)). The main difference between the hydrogen production scenario and the hydrogen purchase scenario is the source of hydrogen. Compared with the purchase scenario, the hydrogen production scenario needs more investment for the separator, reformer and pressure swing adsorption as shown in Fig 2 (a). In addition, a part of the bio-oil in the hydrogen production scenario is used to produce $\mathrm{H}_{2}$ and hence the yield of bio-fuels is reduced. 
All input data related to the stage of fast pyrolysis and hydroprocessing including labor, electricity machinery, catalyst, water and hydrogen are included in Table 5.

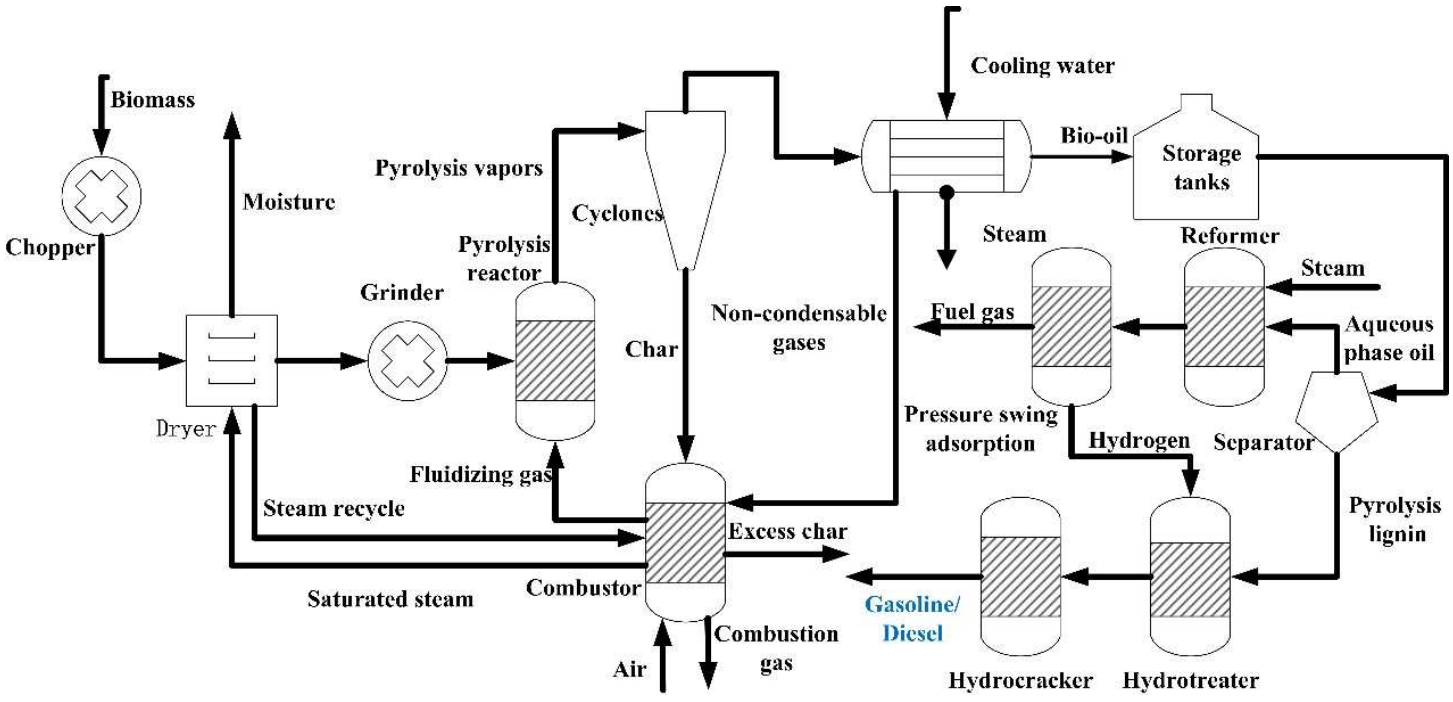

(a) Hydrogen production scenario

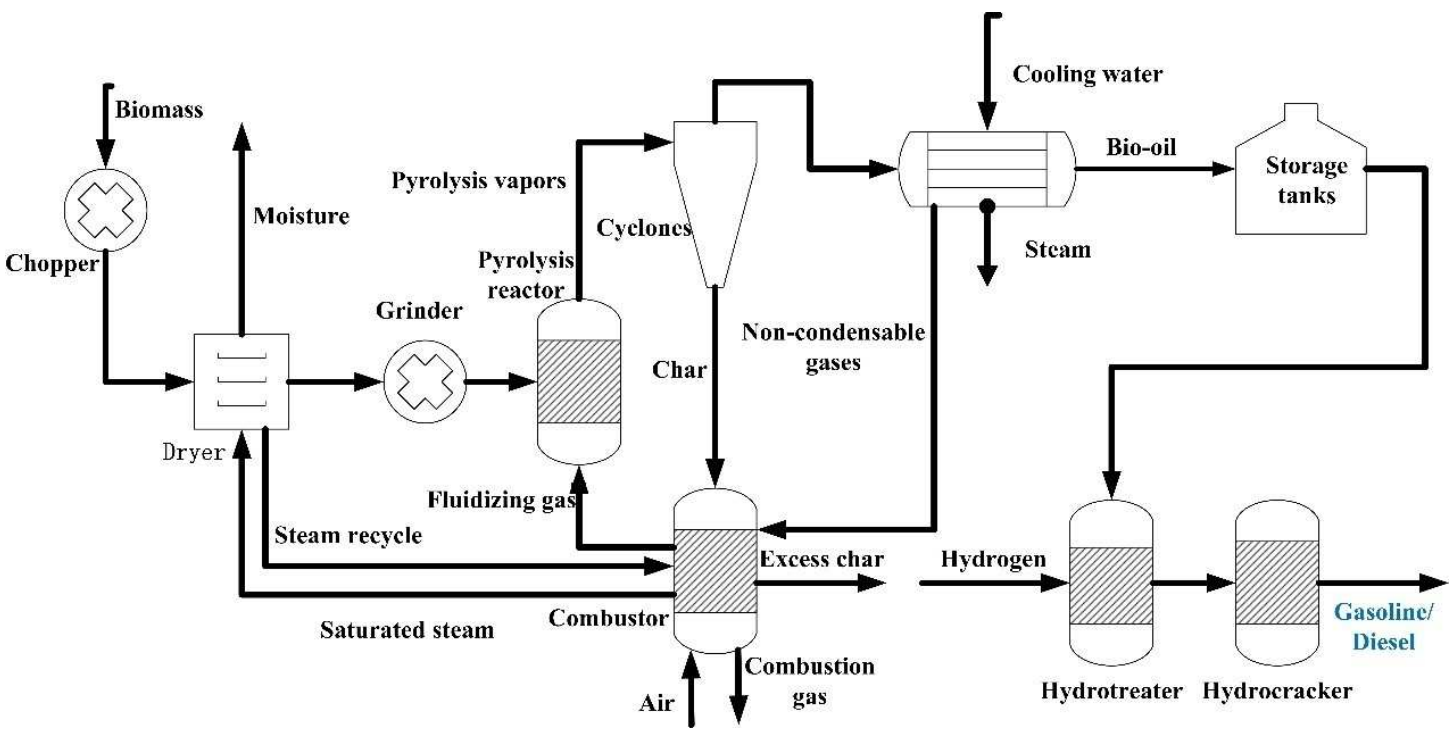

(b) Hydrogen purchase scenario

Fig.2 Process diagrams of the hydrogen production scenario and hydrogen purchase scenario

Table 5 Emergy analysis of stage of fast pyrolysis and hydroprocessing

$\begin{array}{llll} & \text { Transformity } & & \\ \text { Item (J) Class } & & \text { References } & \text { Emergy (sej) } \\ & & & \end{array}$




\begin{tabular}{|c|c|c|c|c|c|c|c|c|c|c|}
\hline & & & & & Case 1 & Case 2 & Case 3 & Case 4 & Case 5 & Case 6 \\
\hline \multirow{3}{*}{24} & Electricity $(\mathrm{J})$ & $\mathrm{F}_{\mathrm{N}}$ & $1.70 \mathrm{E}+05$ & $\mathrm{Li}$ and Yan, & $6.58 \mathrm{E}+$ & $5.59 \mathrm{E}+$ & $6.58 \mathrm{E}+$ & $5.59 \mathrm{E}+$ & $6.58 \mathrm{E}+$ & $5.59 \mathrm{E}+1$ \\
\hline & & & & & & & & & & \\
\hline & & & & 2012 & 19 & 19 & 19 & 19 & 19 & 9 \\
\hline \multirow{2}{*}{25} & Labor $(\$)$ & $\mathrm{F}_{\mathrm{R}}$ & $5.87 \mathrm{E}+12$ & Yang et al., & $1.04 \mathrm{E}+$ & $1.04 \mathrm{E}+$ & $1.04 \mathrm{E}+$ & $1.04 \mathrm{E}+$ & $1.04 \mathrm{E}+$ & $1.04 \mathrm{E}+1$ \\
\hline & & & & 2010 & 19 & 19 & 19 & 19 & 19 & 9 \\
\hline \multirow{3}{*}{26} & Plant & $\mathrm{F}_{\mathrm{N}}$ & $5.87 \mathrm{E}+12$ & Yang et al., & $6.22 \mathrm{E}+$ & $4.68 \mathrm{E}+$ & $6.22 \mathrm{E}+$ & $4.68 \mathrm{E}+$ & $6.22 \mathrm{E}+$ & $4.68 \mathrm{E}+1$ \\
\hline & construction & & & 2010 & 19 & 19 & 19 & 19 & 19 & 9 \\
\hline & $(\$)$ & & & & & & & & & \\
\hline \multirow{2}{*}{27} & Catalyst $(\$)$ & $\mathrm{F}_{\mathrm{N}}$ & $5.87 \mathrm{E}+12$ & Yang et al., & $1.04 \mathrm{E}+$ & $1.04 \mathrm{E}+$ & $1.04 \mathrm{E}+$ & $1.04 \mathrm{E}+$ & $1.04 \mathrm{E}+$ & $1.04 \mathrm{E}+1$ \\
\hline & & & & 2010 & 19 & 19 & 19 & 19 & 19 & 9 \\
\hline \multirow{2}{*}{28} & Water $\left(\mathrm{m}^{3}\right)$ & $\mathrm{F}_{\mathrm{R}}$ & $1.54 \mathrm{E}+12$ & Martin et al, & $3.19 \mathrm{E}+$ & 0 & $3.19 \mathrm{E}+$ & 0 & $3.19 \mathrm{E}+$ & 0 \\
\hline & & & & 2006 & 19 & & 19 & & 19 & \\
\hline \multirow{2}{*}{29} & Hydrogen $(\$)$ & $\mathrm{F}_{\mathrm{N}}$ & $5.87 \mathrm{E}+12$ & Yang et al., & 0 & $1.39 \mathrm{E}+$ & 0 & $1.39 \mathrm{E}+$ & 0 & $1.39 \mathrm{E}+2$ \\
\hline & & & & 2010 & & 20 & & 20 & & 0 \\
\hline \multirow{2}{*}{30} & Solid disposal & $\mathrm{F}_{\mathrm{N}}$ & $5.87 \mathrm{E}+12$ & Yang et al., & $1.04 \mathrm{E}+$ & $1.04 \mathrm{E}+$ & $1.04 \mathrm{E}+$ & $1.04 \mathrm{E}+$ & $1.04 \mathrm{E}+$ & $1.04 \mathrm{E}+1$ \\
\hline & $(\$)$ & & & 2010 & 19 & 19 & 19 & 19 & 19 & 9 \\
\hline \multirow{2}{*}{31} & Insurances & $\mathrm{F}_{\mathrm{N}}$ & $5.87 \mathrm{E}+12$ & Yang et al., & $2.10 \mathrm{E}+$ & $1.46 \mathrm{E}+$ & $2.10 \mathrm{E}+$ & $1.46 \mathrm{E}+$ & $2.10 \mathrm{E}+$ & $1.46 \mathrm{E}+1$ \\
\hline & and taxes $(\$)$ & & & 2010 & 19 & 19 & 19 & 19 & 19 & 9 \\
\hline \multirow{3}{*}{32} & Maintenance & $\mathrm{F}_{\mathrm{N}}$ & $5.87 \mathrm{E}+12$ & Yang et al., & $2.79 \mathrm{E}+$ & $1.94 \mathrm{E}+$ & $2.79 \mathrm{E}+$ & $1.94 \mathrm{E}+$ & $2.79 \mathrm{E}+$ & $1.94 \mathrm{E}+1$ \\
\hline & & & & & & & & & & \\
\hline & $(\$)$ & & & 2010 & 19 & 19 & 19 & 19 & 19 & 9 \\
\hline \multirow{2}{*}{33} & Biofuel (J) & $\mathrm{Y}$ & & & $2.11 \mathrm{E}+$ & 7.74 & $2.11 \mathrm{E}+$ & 7.74 & $2.11 \mathrm{E}+$ & 7.74 \\
\hline & & & & & 15 & $E+15$ & 15 & $E+15$ & 15 & $E+15$ \\
\hline
\end{tabular}


Table 6 Emergy indicators of six cases.

\begin{tabular}{|c|c|c|c|c|c|c|}
\hline Index & Case 1 & Case 2 & Case 3 & Case 4 & Case 5 & Case 6 \\
\hline Total emergy use(U/(sej)) & $4.53 \mathrm{E}+20$ & $5.48 \mathrm{E}+20$ & $1.15 \mathrm{E}+21$ & $1.24 \mathrm{E}+21$ & $6.38 \mathrm{E}+21$ & $6.48 \mathrm{E}+21$ \\
\hline Transformity(Tr/(sej/J)) & $2.15 \mathrm{E}+05$ & $7.08 \mathrm{E}+04$ & $5.44 \mathrm{E}+05$ & $1.61 \mathrm{E}+05$ & $3.02 \mathrm{E}+06$ & $8.37 \mathrm{E}+05$ \\
\hline Emergy yield ratio(EYR) & 1.055 & 1.045 & 1.080 & 1.073 & 1.106 & 1.105 \\
\hline Environmental loading & 5.64 & 7.42 & 0.73 & 0.89 & 0.10 & 0.12 \\
\hline \multicolumn{7}{|l|}{ ratio(ELR) } \\
\hline Emergy sustainability & 0.19 & 0.14 & 1.47 & 1.21 & 10.69 & 9.16 \\
\hline index(ESI) & & & & & & \\
\hline
\end{tabular}

242

\subsection{Emergy inputs of the selected six cases}

As shown in Table 6, the total emergy uses (U) of the six cases are4.53E+20sej, 5.48E+20sej, 1.15E+21sej, 1.24E+21 sej, $6.38 \mathrm{E}+21$ sej and $6.48 \mathrm{E}+21$ sej, respectively. Compared with the fields in NECP and in NCP, the fields in SXP are poorer and need more materials and energy inputs to produce the same quantity of corn stover. The distributions of all emergy inputs of the six cases are presented in detail in Figure 3. In NECP, the three biggest emergy input flows forCase 1 are fertilizer, electricity and plant construction $(37.2 \%, 14.5 \%$ and $13.7 \%$, respectively), whereas for Case 2 they are fertilizer, hydrogen and electricity $(30.7 \%, 25.3 \%$ and $10.2 \%$, respectively). In NCP, the three biggest emergy input flows forCase 3 are water, diesel fuel and fertilizer $(45.4 \%, 10.4 \%$ and $10.2 \%$, respectively) but for Case 4 , they are water, hydrogen and 
diesel fuel $(41.7 \%, 11.1 \%$ and $9.6 \%$, respectively). In SXP, the three biggest emergy input flows for both Case5 and Case 6 are labor, rain and fertilizer $(78.7 \%, 7.7 \%, 6.4 \%$ for Case 5 and $77.5 \%, 7.5 \%, 6.3 \%$ for Case 6, respectively). These results indicate that when stakeholders/decision-makers want to introduce policies and measures aiming to reduce the resource inputs and increase the sustainability of a corn stover-based biofuel system, they need to pay more attention to the required input flows of fertilizer, water, diesel fuel and hydrogen. The proportions of the four categories $\left(R, N, F_{N}\right.$ and $\left.F_{R}\right)$ of emergy inputs to the corn stover-based biofuel systems are shown in Fig.4.In each region, the percentages of the four categories are almost identical for the two different scenarios. In NECP, $\mathrm{F}_{\mathrm{N}}$, the inorganic assistant energy, is the biggest category of emergy input, contributing $84.2 \%$ (Case 1) and $87.5 \%$ (Case 2) of the total emergy input, and followed byF $F_{\mathrm{R}}$ (organic assistant energy), $\mathrm{R}$ (renewable environmental resources) and $\mathrm{N}$ (non-renewable environmental resources) which contribute $10.6 \%, 4.5 \%$ and $0.7 \%$ to the total emergy input in Case 1, and $8.2 \%, 3.7 \%$ and $0.6 \%$ in Case 2. However, in both NCP and SXP, $\mathrm{F}_{\mathrm{R}}$ is the biggest category of emergy input accounting for $52.2 \%$ (Case 3), 48.0\% (Case 4), 81.7\% (Case 5) and 83.0\% (Case 6), respectively. In NCP, $\mathrm{F}_{\mathrm{N}}, \mathrm{R}$ and $\mathrm{N}$ are the $2^{\text {nd }}, 3^{\text {rd }}$ and $4^{\text {th }}$ biggest category of the emergy input, accounting for $40.4 \%, 5.4 \%$ and $1.9 \%$ (Case 3), and $45.2 \%, 5.4 \%$ and $1.8 \%$ (Case 4$).$ In SXP, the $2^{\text {nd }}$, $3^{\text {rd }}$ and $4^{\text {th }}$ biggest category of the emergy input are $\mathrm{R}, \mathrm{F}_{\mathrm{N}}$ and $\mathrm{N}$ for Case 5 , accounting for $7.7 \%, 7.4 \%$ and $2.0 \%$, but for Case 6 , they are $\mathrm{F}_{\mathrm{N}}, \mathrm{R}$ and $\mathrm{N}$ which account for $8.8 \%$, $7.5 \%$ and $1.9 \%$ of the total emergy input. A large amount of inorganic assistant energy $\left(\mathrm{F}_{\mathrm{N}}\right)$ in NECP has contributed to lower sustainability of the biofuel production systems 
in this region. Fig.4 also shows that similar to other industrial systems the major inputs of the resources to the biofuel production systems come from economy $\left(F_{N}\right.$ and $\left.F_{R}\right)$ for all 6 cases. As it can be seen fromFig.5,the stage with the biggest emergy input for all of the 6 cases considered except Case 2 is maize production (Case $1-52.3 \%$, Case 3 $80.8 \%$, Case $4-74.9 \%$, Case $5-96.6 \%$, Case $6-95.2 \%$ ). This indicates the agriculture phase is responsible for the highest fraction of resources used in the whole production system, which is in agreement with biodiesel production from sunflower and other oleaginous crops (Spinelli et al., 2012; Spinelli et al., 2013; Takahashi and Ortega, 2010).For Case 3, fast pyrolysis and hydroprocessing is the biggest emergy input stage, followed by maize production. The second biggest emergy input stage for all of the 6 cases except Case 3 is fast pyrolysis and hydroprocessing. The results shown in Fig. 5 also indicate that the emergy inputs due to collection and transportation are negligible for all 6 cases.

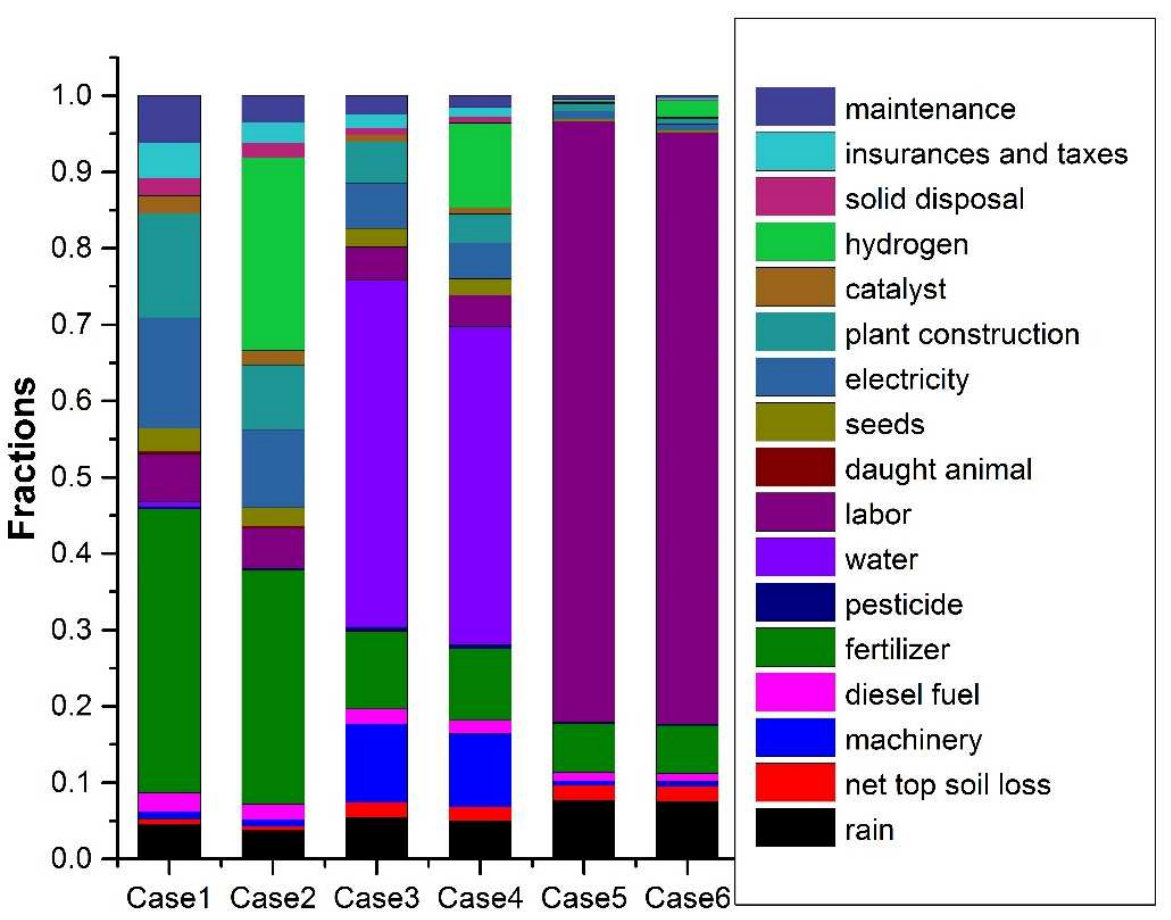




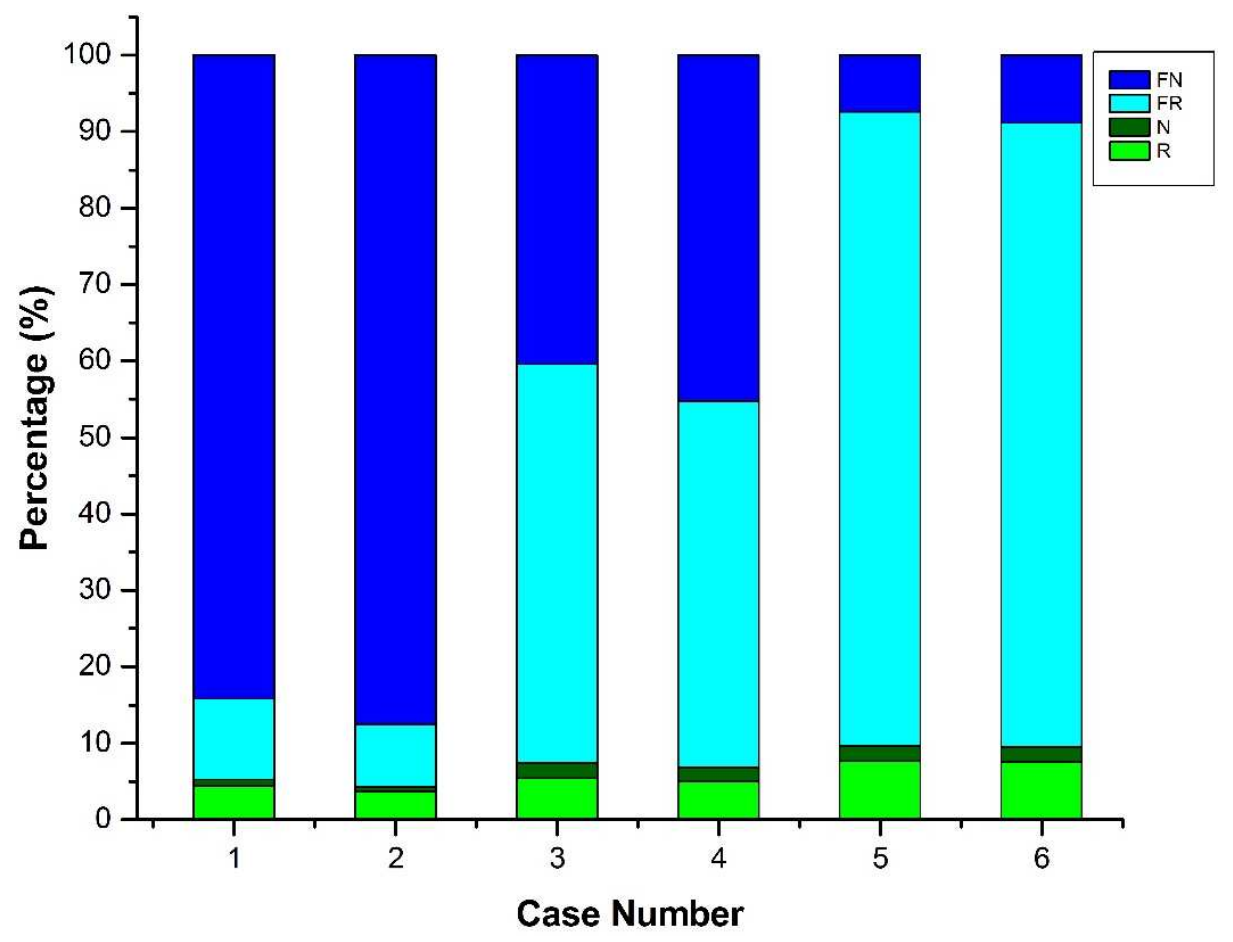

Fig. 4 The proportion of four categories of emergy inputs to the total emergy input of the selected six cases

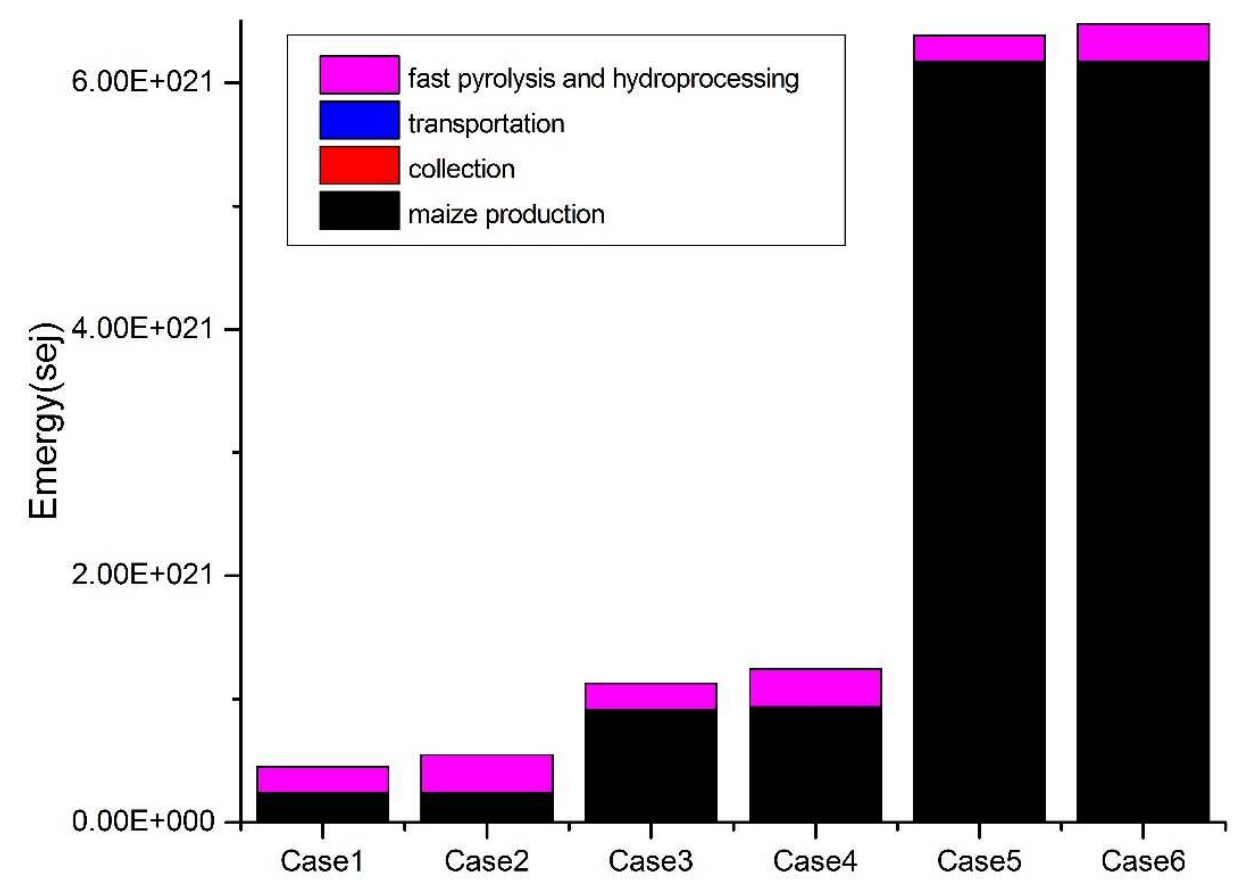

Fig. 5 Emergy inputs during four stages of the selected six cases

\subsection{Emergy indices}

Four emergy based indicators (Tr, EYR, ELR and ESI) of the 6 cases are calculated.The 
301

302

details about these emergy based indicators are discussed below.

\subsubsection{Transformity (Tr)}

Transformity can measure how much emergy it takes to generate one unit of output and the efficiency of the system. Inother words, a process with a lower transformity value but with the same output means more efficient as the same amount of emergy inputs results in greater productions or services, or the same quantity of productions or services needs less emergy inputs (Odum, 1988; Zhang et al., 2014;Goh and Lee, 2010). As shown in Table 6 , the $\operatorname{Tr}$ valuesof the 6 cases are2.15E+05 sej/J, 7.08E+04 sej/J, $5.44 \mathrm{E}+05 \mathrm{sej} / \mathrm{J}, 1.61 \mathrm{E}+05 \mathrm{sej} / \mathrm{J}, 3.02 \mathrm{E}+06 \mathrm{sej} / \mathrm{J}$, and $8.37 \mathrm{E}+05 \mathrm{sej} / \mathrm{J}$, respectively. The ranking from high to low efficiency follows the order of Case 2, Case 4, Case 1, Case 3, Case 6 and Case 5. The high efficiency of Case 2 was expected mainly due to its high corn stover yields each year (11.8t/ha). All of these Tr values except that of Case 2 are higher than those of coal $(6.71 \mathrm{E}+04 \mathrm{sej} / \mathrm{J})$, natural gas $(8.05 \mathrm{E}+04 \mathrm{sej} / \mathrm{J})$ and crude oil $(9.07 \mathrm{E}+04 \mathrm{sej} / \mathrm{J})($ Odum, 1996).Therefore, the results of the emergy analysis indicate that the fossil fuels made by nature are more efficient than the biofuels produced by human. Compared with other biofuels seen in Table 7, Case 2 is also more efficient than ethanol from cassava chips and sugarcane, and biodiesel from soybean, sunflower and cotton. However, it has no advantage over biodiesel from canola and oil palm. Case 2 can be more competitive if the issue of food security affecting the biodiesel production from canola and oil palm is taken into account. Therefore, it can be concluded that the biofuel production via fast pyrolysis and hydroprocessing of corn stover can be one of the best biofuel production routes. 
Table 7 Comparison of the Tr value of Case 2 with those of other biofuels

\begin{tabular}{ccc}
\hline \multicolumn{1}{c}{ biofuels } & $\operatorname{Tr}(\mathrm{sej} / \mathrm{J})$ & References \\
\hline Ethanol from sugarcane & $1.86 \mathrm{E}+05-3.15 \mathrm{E}+05$ & Cavalett and Ortega, 2010 \\
Biodiesel from sunflower & $2.31 \mathrm{E}+05-2.78 \mathrm{E}+05$ & Cavalett and Ortega, 2010 \\
Biodiesel from soybean & $3.18 \mathrm{E}+05$ & Cavalett and Ortega, 2010 \\
Ethanol from cassava chips & $1.10 \mathrm{E}+05$ & Yang, 2011 \\
Biodiesel from canola & $4.37 \mathrm{E}+04$ & Takahashi and Ortega, 2010 \\
Biodiesel from oil palm & $2.39 \mathrm{E}+04$ & Takahashi and Ortega, 2010 \\
Biodiesel from cotton & $1.56 \mathrm{E}+06$ & Takahashi and Ortega, 2010 \\
Case 2 & $7.08 \mathrm{E}+04$ & This study \\
\hline
\end{tabular}

\subsubsection{Emergy yield ratio (EYR)}

EYR is a useful indicator to reflect the ability of a process or system to explore locally available resources by investing purchased inputs. Indeed, EYR is analogous to Hill's energy return on energy invested (EROI) (Goh and Lee, 2010) and is a return on emergy invested through purchased inputs. The higher the EYR value, the greater the system yield per purchased input emergy (Chen et al., 2006; Tao et al., 2013; Wang et al., 2014). As seen in Table 6, the EYR values of the 6 cases are all within the range of between 1.045 and 1.106 (Case1-6: 1.055, 1.045, 1.080, 1.073, 1.106, and 1.105) and similar to other biofuels (Ren et al., 2013; Yang, 2011; Yang et al., 2010). The EYR values of Case 2 and Case 5 are the lowest and the highest, indicating that Case 5 has the highest production efficiency.

\subsubsection{Environmental loading ratio (ELR)}



ELR value, the more non-renewable resources are consumed and the greater the load on environment. Generally, production systems can be divided into three grades: low environment impacts, ELR $\leq 2$; moderate environment impacts, $2<\mathrm{ELR}<10$; large environment impacts, ELR $\geq 10$ (Zhang et al., 2014; Wang et al., 2014). Shown in Table

6 , the ELR values of the 6 cases are $5.64,7.42,0.73,0.89,0.10$ and 0.12 , respectively and therefore, Case 1 and Case 2 belong to the category of moderate environment impacts, while Case 3-6 belong to the category of low environment impacts. The ELR calculated in Case 2 is the highest, indicating it requires the most intensive nonrenewable emergy input and has the highest environmental stress among the 6 cases. The lowest value of ELR in Case 5 represents that there is plenty space for future development.

\subsubsection{Emergy sustainability index (ESI)}


belong to the high-consumption economic system, Case 3, Case 4 and Case 6 have excellent sustainability but Case 5 is considered undeveloped. Base on the values of ESI, NCP(for both Case 3 and Case 4) is regarded as the best region in China to build plants for producing biofuels from corn stover.

\section{Discussion}

\subsection{Comparison of the 6 cases}

The $\operatorname{Tr}$ value usually measures the production efficiency of a process, and ESI, calculated as the ratio between EYR and ELR, is always used to evaluate sustainability of a system. Therefore, which region is most suitable for building a biofuel production plant can be firstly identified by comparing values of $\operatorname{Tr}$ and ESI of the 6 cases. As shown in Fig. 6, Case2 is the most efficient, but their sustainability is not acceptable. As the maize-maize continuous cropping system dominates in NECP (Zhang et al., 2015), large amounts of purchased inputs such as fertilizer and water are required to maintain high maize yields. The biofuel production systems in NECP are highly developed "consumer" oriented economies, therefore, NECP is not the most suitable region for constructing plants to produce biofuels. Case 5 and Case 6 in SXP have relatively low efficiency, and hence have great potential to improve. Maize production in SXP consumes a lot of labor, indicating that agricultural mechanization level is low. In order to make the whole producing system more sustainable in SXP, more agricultural machinery should be used to improve the production efficiency. Case 3 and Case 4 in NCP exhibit strong economic viability as well as excellent sustainability, and their production efficiencies are moderate. Therefore, NCP is the best region for 
building plants to utilize the crop residue.

The yields of bio-oil from fast pyrolysis in all cases are the same (Wright et al., 2010). However, in the hydrogen production scenario (Case 1, Case 3 and Case 5), part of the bio-oil is used for producing hydrogen, therefore, the yield of bio-gasoline and bio-diesel $(2.11 \mathrm{E}+15 \mathrm{~J})$ is much lower than that of the hydrogen purchase scenario cases (Case 2, Case 4 and Case 6) (7.74E+15 J). In each region, the Tr value of the hydrogen purchase scenario is much lower than that of the hydrogen production scenario, indicating that more products are obtained with the same amount of emergy input to the production system. Therefore, in any of the three main maize production regions, the hydrogen purchase scenario is always more efficient than the hydrogen production scenario. Consequently, the hydrogen purchase scenario in NCP (Case 4) is the best choice to produce transportation fuels from corn stover due to its second sustainability and second highest production efficiency.
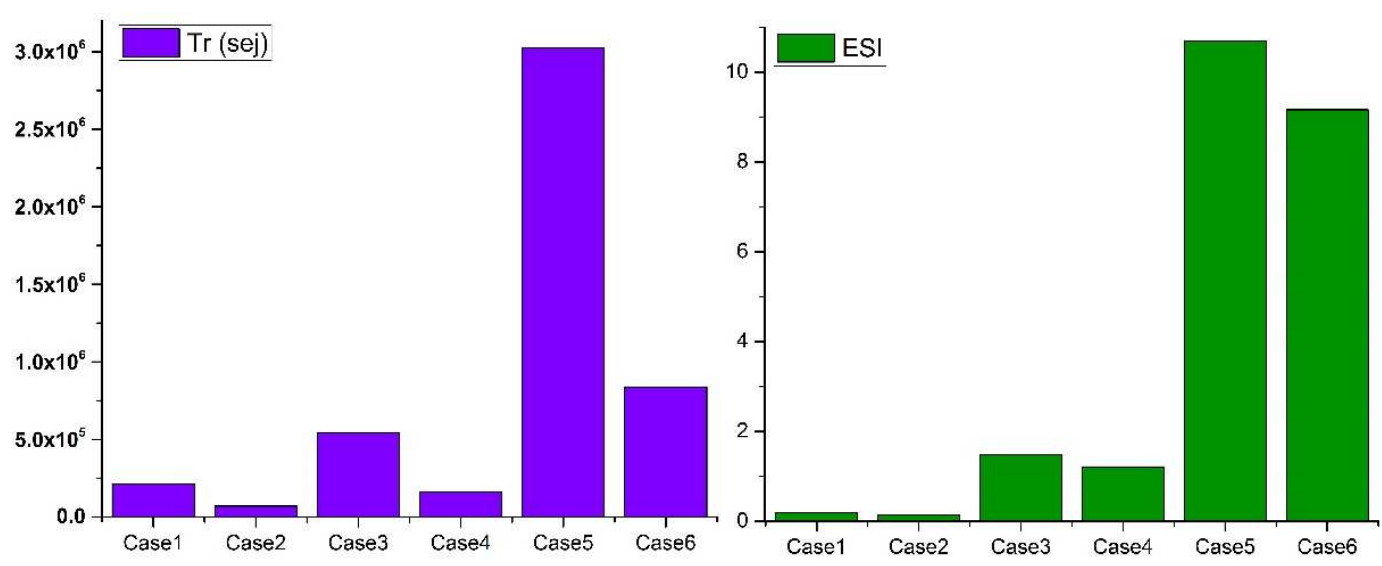

Fig.6 Tr and ESI of the corn stover-based biofuel systems

\subsection{Comparison with other biofuel production pathways in China}

In Italy, literature have focused on biofuels from sunflower, microalgae and 
microalgae (Spinelli et al., 2012; Spinelli et al., 2013; Cruz and Nascimento, 2012; Bastianoni et al., 2008), and in Brazil, research and development have centered on the production of biofuels from oleaginous crops providing raw material such as vegetable oil and soybean (Cavalett and Ortega, 2010), due to the abundantly available such kinds of feedstock in these two countries. But in China, there are a lot of wheat, maize, rice, cassava and other agricultural residues that can be used as feedstock for the production of biofuels. Emergy analyses of biofuels from wheat, cassava chips Jatropha curcas L in China were reportedby Ju and Chen (2011), Dong et al. (2013) and Yang (2011) and the results are summarized in Table 8. Compared with other biofuel production pathways in China, Case 4 has the best sustainability and the second highest production efficiency. Although bioethanol from cassava chips has the highest production efficiency, Case 4 still has most potential for industrialization as the cassava production system competes for land and water that are used for food and fiber production. Therefore, Case 4 can be considered as the best biofuel production pathway in China based on the emergy analysis of this study and previous work of others (Yang, 2011; Ju and Chen, 2011, Dong et al., 2013).

Table8 Comparison of Tr and EIS of liquid biofuels in China

\begin{tabular}{ccccc}
\hline liquid biofuels & Feedstock & Reference & $\operatorname{Tr}(\mathrm{sej} / \mathrm{J})$ & ESI \\
\hline bioethanol & cassava chips & Yang, 2011 & $1.10 \mathrm{E}+05$ & 0.63 \\
biodiesel & jatrophacurcas L & Ju and Chen, 2011 & $3.95 \mathrm{E}+05$ & 0.364 \\
bioethanol & wheat & Donget al., 2013 & $2.77 \mathrm{E}+05$ & 0.31 \\
Case 4 & corn stover & This work & $1.58 \mathrm{E}+05$ & 1.21 \\
\hline
\end{tabular}




\subsection{Sensitivity analysis} average haulage distance depends on the distance between the biomass production site and the biofuel production plant. Hydrogen price changes according to supply and
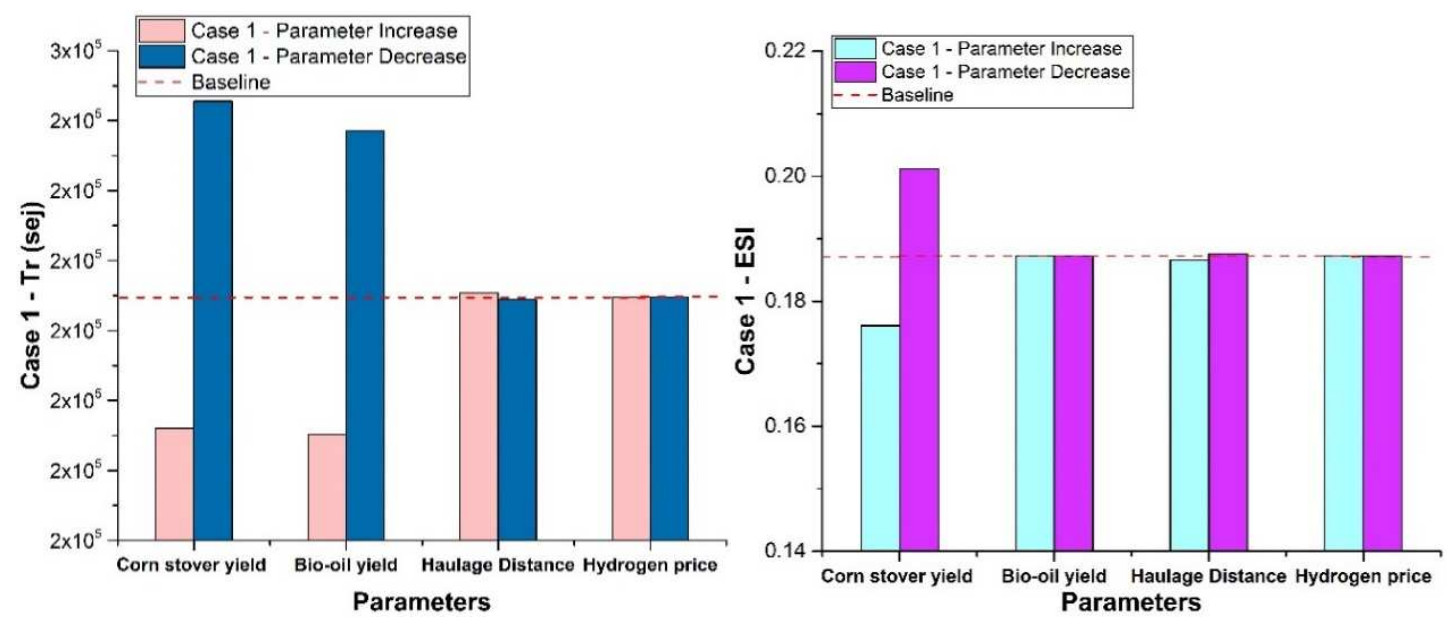

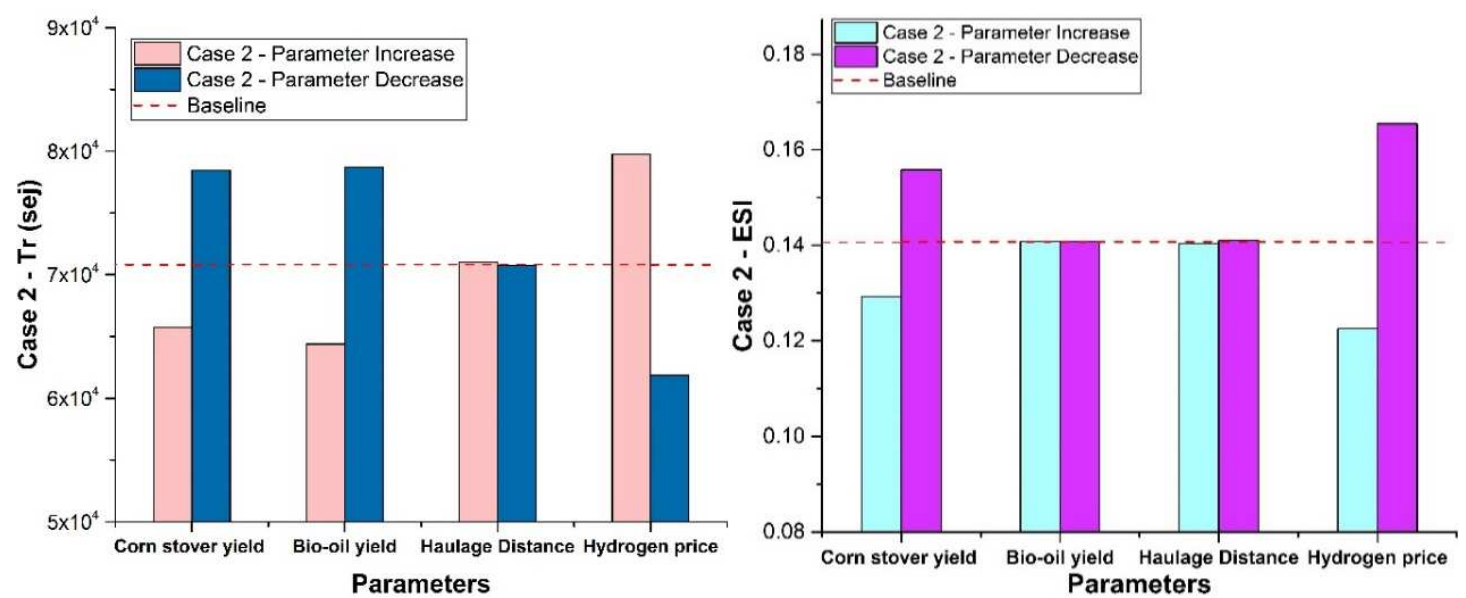

Parameters
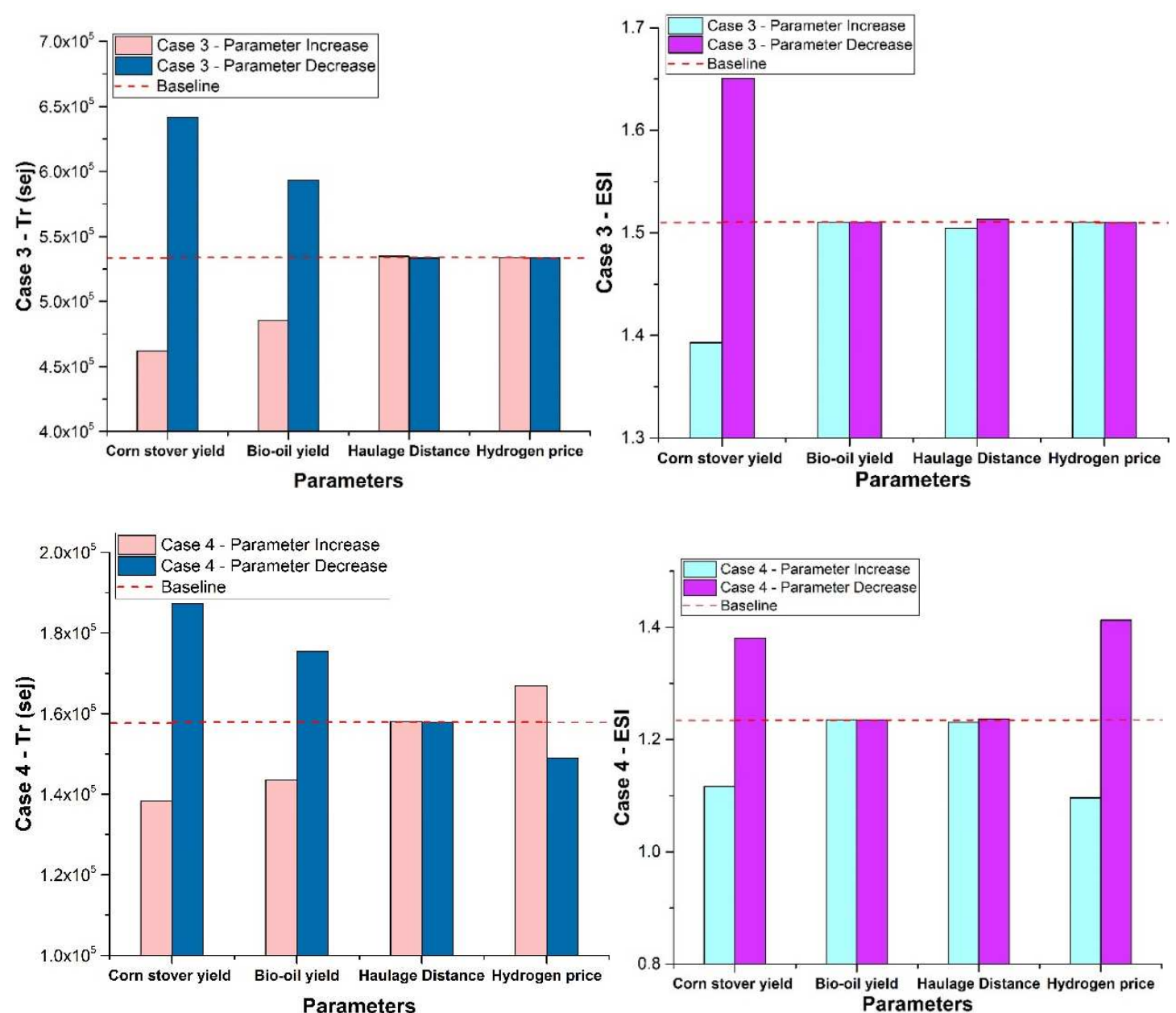

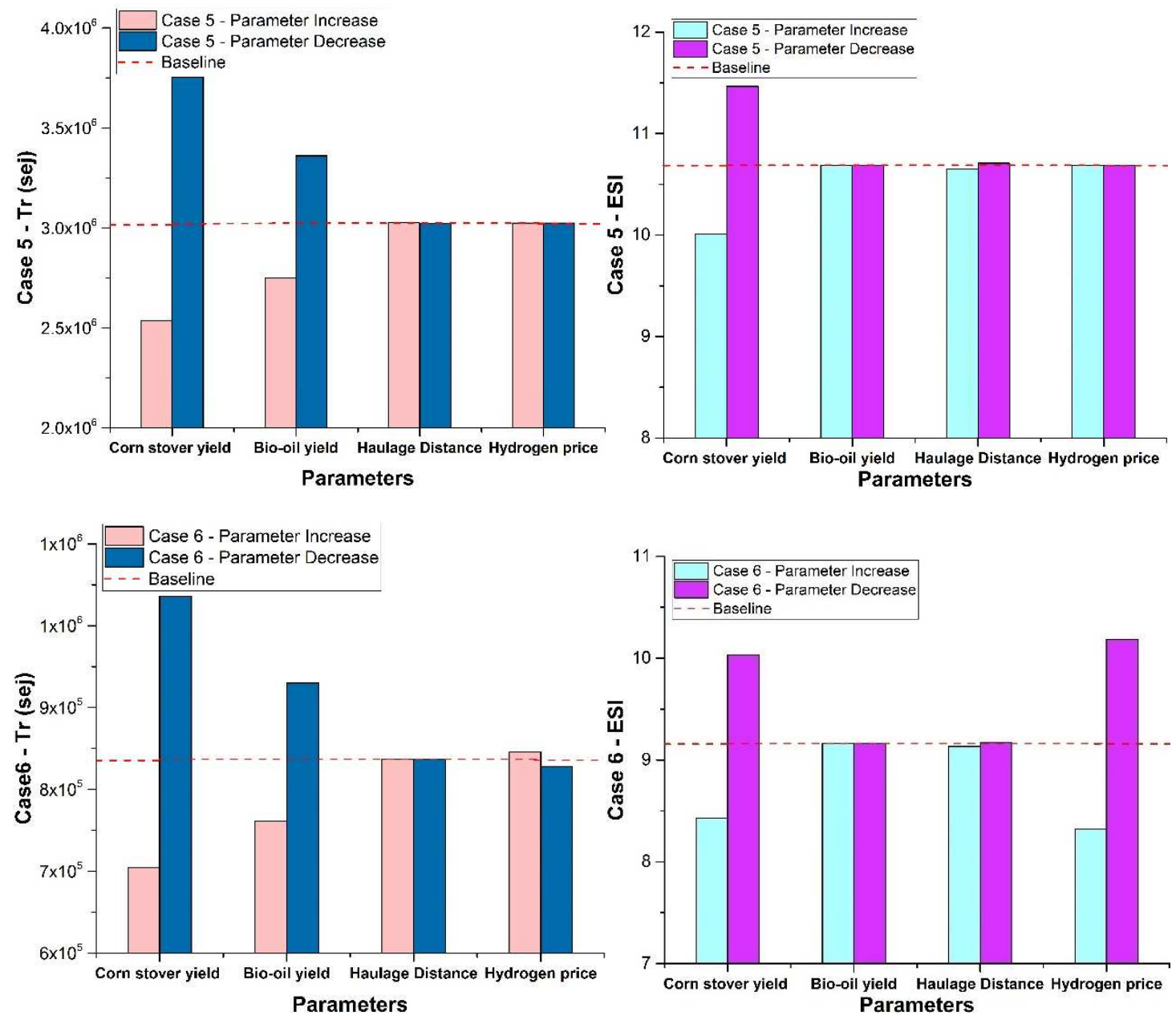

Fig. 7 Results of sensitivity analysis

The results of sensitivity analysis are shown in Fig.7. It can be seen that corn stover

yield has the greatest impact on Tr values in all cases except Case 2.For Case 2, the most important parameter affecting Tr value is hydrogen price. Corn stover yield also has the greatest impact on ESI values in the hydrogen production scenario cases (Case 1, Case 3 and Case 5). Hydrogen price is the most important parameter affecting ESI values of the hydrogen purchase scenario cases (Case 2, Case 4 and Case 6). Bio-oil yield is the second most influential parameter on $\operatorname{Tr}$ values for all 6 cases but it has no

441 effect on the sustainability of any of the biofuel production systems (i.e. ESI of each system).Biomass average haulage distance has little influence on the $\operatorname{Tr}$ and ESI values 
change is well below $1 \%$. The results of sensibility analysis indicate that more attention should be given to the improvement of corn stover yield and hydrogen price in order to achieve better production efficiency and sustainability of the biofuel production system. Further, Case 4 with the four parameters varying within the specified ranges still acquires the second best production efficiency and the second best sustainability among all 6 cases, with $\operatorname{Tr}$ varying from $1.38 \mathrm{E}+5$ to $1.87 \mathrm{E}+5$ sej and ESI varying from 1.10 to 1.41.Comparing with other biofuel production pathways in China (Table 5), it still achieves the best sustainability and the second highest production efficiency. Therefore, it can be concluded that Case 4 is expected to bethe best case for the biofuel production plant in China even the main characteristic factors of the production plant may differ from their baseline values considered in this study.

\subsection{Improvement measures}

Based on the results of the emergy input analysis and emergy indices of the biofuel production systems, the hydrogen purchase scenario in NCP (Case 4) is considered to be the best choice for biofuel production using corn stover in China. Maize production and fast pyrolysis and hydroprocessing are the two major stages in Case 4, with 74.9\% and $24.6 \%$ of total emergy inputs. In addition, these two processes have significant influences on the corn stover yield and bio-oil yield, respectively. Therefore, there are large amounts of emergy inputs on water, fertilizer and hydrogen, meaning that the production efficiency and sustainability of the production system can be enhanced by improving water and fertilizer management and hydrogen production technology.

The soil condition and climate in NCP are suitable for growing winter wheat and 
summer maize as a double-crop system. The total emergy inputs to the fields per year support for both wheat growing and maize growing. Therefore, all measures to reduce irrigation water and fertilizer used for both wheat growing and maize growing in NCP are briefly discussed below.

\subsubsection{Water management}

The optimal amounts of irrigation water for winter wheat and summer maize are $186 \mathrm{~mm}, 161 \mathrm{~mm}, 99 \mathrm{~mm}$ and $134 \mathrm{~mm}, 88 \mathrm{~mm}, 0 \mathrm{~mm}$ in the dry, normal, and wet seasons in NCP (Sun et al., 2010). According to the season precipitation and characteristics of grain growing, irrigation schedules are regulated to be suitable for grain production (Sun et al., 2006; Zhang et al., 2003). One to three times of irrigation (each 75-80mm) is optimal for NCP, and pre-sowing irrigation of winter wheat is needed for achieving high yield and high water use efficiency. However, excessive irrigation may not improve the grain yields (Hu et al., 2010; Zhao et al., 2015). In addition, straw mulching with wheat and maize can reduce soil evaporation and improve water-use efficiency, and consequently reduce the application of irrigation water and improve the grain production (Zhang et al., 2003). Finally, promotion of water-saving incentives, efficient water-saving technologies and enforcement of sustainable water manage policies can also be used to improve water use efficiency (Hu et al., 2010).

\subsubsection{Fertilizer management}

Commonly, on average, $170 \mathrm{~kg} \mathrm{~N} / \mathrm{ha}, 32 \mathrm{~kg} \mathrm{P} / \mathrm{ha}$, and $130 \mathrm{~g} \mathrm{~K} / \mathrm{ha}$ for wheat, $189 \mathrm{~kg} \mathrm{~N} / \mathrm{ha}, 34 \mathrm{~kg} \mathrm{P} / \mathrm{ha}$, and $212 \mathrm{~g} \mathrm{~K} /$ ha for maize are required to achieve the productivity of wheat (6.9t/ha) and maize (8.3t/ha) in NCP (Wang et al., 2010).Compost 
fertilizers with low transformity result in higher grain yields (Zhao et al., 2013). Organic fertilizers also have lower transformity and can improve soil fertility and quality (Miao et al., 2011). Therefore, compost fertilizers and Organic fertilizers can be used to replace chemical fertilizers to improve sustainability of the system. According to soil tests, yield targets, all nutrients including $\mathrm{N}, \mathrm{P}$, and $\mathrm{K}$ should be applied at the optimum rates before sowing to avoid the grain yield gap, which can reduce $\mathrm{N}$ and $\mathrm{P}$ inputs in the areas with nutrients over applied, balance the soil nutrient levels and improve nutrients use efficiency (He et al., 2009). Further, appropriate information and knowledge on improving the use efficiency of nutrients must be provided to the millions of farmers by the central and/or local administrative departments of agriculture in China (Liu et al., 2011; Huang et al., 2012).

\subsubsection{Hydrogen production technology}

Natural gas steam reforming is the most common hydrogen production method and meets around 50\% of the global hydrogen demand, while $30 \%$ of hydrogen production comes from oil reforming, with $18 \%$ from coal gasification, $3.9 \%$ from water electrolysis and $0.1 \%$ from other resources (Muradov and Vezirolu, 2005; Dincer and Acar, 2015). Most of hydrogen in commercial use today is produced from fossil fuels due to its low cost and efficient purification but it is also associated with some shortcomings such as high capital, operation and maintenance cost and non-renewable. Hydrogen production methods from renewable resources such as water and biomass are fast developing. In this study, the hydrogen production scenario from corn stover has no production efficiency advantage over the hydrogen purchased scenario, indicating 
that the hydrogen production technology from corn stover is not a better way to produce hydrogen than those commercially available on the market at present. Maybe hydrogen production methods from other biomass (not corn stover) are better than natural gas steam reforming. Like an ecological food chain, the more energy transformation hierarchies are, the more solar energy input to maintain the "consumer" in the highest hierarchy, resulting in a higher solar transformity (Howard, 1988). Therefore, hydrogen from biophotolysis, photofermentation and photoelectrolysis should have lower transformities due to directly decomposing water by sunlight. However, it is generally accepted that solar energy-based hydrogen production methods will be unlikely to yield significant reduction in economic cost in the near future (Muradov and Vezirolu, 2005;

Dincer and Acar, 2015). With the advance of these hydrogen production technologies the biofuel production system from corn stover will become more efficient and sustainable.

\subsection{Policy implications}

The biofuel production system via the fast pyrolysis and hydroprocessing of corn stover is a complex process involving many sectors such as agriculture, transport sector, industrial sector, scientific research institutes and technology developer. Collaborative efforts and supports from these sectors are needed to promote this biofuel production method for large scale industrial application, for example:

(1)The agriculture department of the government needs to collect enough information about maize growing and wheat growing. The annual statistical data about the mount of fertilizer and water needed for achieving optimal maize yield and wheat yield are 
used for predicting the best mounts of fertilizer and water needed for the next year. The farmers can easily get these useful information through lessons organized by local government or other public media. In addition, the government should encourage large scale farms instead of individual family farms as large farms are conducive to fertilizer and water management. Government can set up subsidies and tax exemption to encourage relevant companies to sign an agreement with farmers to purchase corn stover collected from the field instead of abandoning corn stover as waste or being burned in the field. These actions can increase farmers' income and improve farmers' enthusiasm for collecting corn stover.

(2)Some actions need to be taken by the transport sector, for example, to modify current pipelines, pumping stations, and vehicles to make them suitable for the biofuels from corn stover. Subsidies and tax exemption can beset up to promote drivers and haulage companies to use biofuel from corn stover, which can increase biofuels' market competitiveness.

(3) Industrial sector can promote the use of biofuels produced from corn stover, for example, by encourage manufacturers to design and manufacture equipment compatible with the biofuel.

(4) Scientific research institutes and technology developers can improve the efficiency and sustainability of the biofuel, for example, through improving biofuel yield and developing more efficient solar energy-based hydrogen production methods such as biophotolysis, photofermentation and photoelectrolysis.

\subsection{Limits and drawbacks}



and sustainability of the whole biofuel production system. However, there are still some limits and drawbacks:

(1) The data of maize production stage are collected from different open literature

558

sources. Therefore, there are some inconsistencies among the data sources, for example, the data collected in different regions in China are in different years. In addition, the data only reflect the maize production in a particular year, while the average data over five years or more in one region are expected to be more suitable for evaluating the production efficiency and sustainability of the whole biofuel production system in this region.

(2) The data of fast pyrolysis and hydroprocessing are adopted from the simulation results using software Aspen plus (Wright et al., 2010) as there is no real large-scale plant producing biofuels from corn stover. The influence of the difference between the simulation plant data and the real plant data is not clear but can be significant.

(3) The differences in hydrogen prices between three regions are ignored as many factors influence the prices including the supply and demand to the market during the operation period of each biofuel plant.

\section{Conclusions}

The present study has evaluated the efficiency and sustainability, using emergy analysis, of two biofuel production scenarios (the hydrogen production scenario and the hydrogen purchase scenario) via fast pyrolysis and hydroprocessing of corn stover in three main maize production regions in China: NECP, NCP and SXP. The analysis of 
the emergy input structure has shown that the maize production stage has the biggest emergy input, while the fast pyrolysis and hydroprocessing stage has the second biggest emergy input, for all 6 selected cases. Most of the inputs come from non-renewable resources from economy. Four biggest emergy input flows of the whole biofuel production system are fertilizer, water, hydrogen and electricity and hence must be given more attention in order to improve the efficiency and sustainability of the biofuel production system. Among the 6 cases considered, the hydrogen purchase scenario in NCP, i.e., Case 4 is the best plan for the corn stover-based biofuel production system due to the combination of its second best sustainability and second best production efficiency. In addition, Case 4is also found to be a better biofuel production pathway comparing with other liquid biofuel production routes in China such as bioethanol from cassava chips and wheat, and biodiesel from jatropha curcas L. According to the results of sensitivity analysis, the corn stover yield has the greatest impact on the sustainability and production efficiency of the hydrogen production scenario while for the hydrogen purchase scenario the most influential parameter is the hydrogen price. The importance and potential measures of improving water management, fertilizer management and hydrogen production technology and policy applications to make the hydrogen purchase scenario in NCP(Case 4) more efficient and sustainable have been highlighted and put forward for the attention of the relevant sectors and stakeholders of this important biofuel production system. The results of this study can serve as useful guide to the future research, development and industrial application of biofuel production from corn stover in China and other parts of the world. 
598

599

600

601

602

603

604

605

606

607

608

609

610

611

612

613

614

615

616

617

618

619

\section{Acknowledgments}

The authors gratefully acknowledge the financial support from National Key Technology Research and Development Program of the Ministry of Science and Technology of China (2015BAD21B06), National Key Basic Research Program of China (2013CB228106) and Jiangsu Province Science and Technology Support Project (BE2013705) on this work. The authors would also like to acknowledge the provision of a scholarship to Mr Changqi Liu by the China Scholarship Council (CSC) which enables him to be able to complete part of the reported work at the University of Nottingham.

\section{References}

Anex, R.P., Aden, A., Kazi, F.K., Fortman, J., Swanson, R.M., Wright, M.M., Satrio, J.A., Brown, R.C., Daugaard, D.E., Platon, A., Kothandaraman, G., Hsu, D.D., Dutta, A., 2010. Techno-economic comparison of biomass-to-transportation fuels via pyrolysis, gasification, and biochemical pathways. Fuel. 89, S29-S35.

Baral, N. R., Wituszynski, D. M., Martin, J. F., \& Shah, A., 2016.Sustainability assessment of cellulosic biorefinery stillage utilization methods using emergy analysis. Energy. 109, 13-28.

Bastianoni, S., Coppola, F., Tiezzi, E., Colacevich, A., Borghini, F., Focardi, S., 2008.Biofuel potential production from the Orbetello lagoon macroalgae: A comparison with sunflower feedstock. Biomass. Bioenerg. 32, 619-628.

Bridgwater, A.V., 2012. Review of fast pyrolysis of biomass and product upgrading. Biomass. Bioenerg. 38, 68-94. 
620

621

622

623

624

625

626

627

628

629

630

631

632

633

634

635

636

637

638

639

640

641

Brown, M.T., Ulgiati, S., 1997.Emergy-based indices and ratios to evaluate sustainability: monitoring economies and technology toward environmentally sound innovation. Ecol. Eng. 9, 51-69.

Brown, M.T., Ulgiati, S., 2002.Emergy evaluations and environmental loading of electricity production systems.J. Clean. Prod. 10, 321-334.

Brown, M. T., \&Ulgiati, S., 2010. Updated evaluation of exergy and emergy driving the geobiosphere: a review and refinement of the emergy baseline. Ecol. Model. 221(20), 2501-2508.

Cao, Y., Shen, H., 2012. A research on collection cost in the process of straw power generation. Elec PowerEnerg, 33 (05), 463-466. (in Chinese)

Cavalett, O., Ortega, E., 2010. Integrated environmental assessment of biodiesel production from soybean in Brazil. J. Clean. Prod. 18, 55-70.

Chen, G.Q., Jiang, M.M., Chen, B., Yang, Z.F., Lin, C., 2006. Emergy analysis of Chinese agriculture. Agr.Ecosyst.Enviro. 115, 161-173.

Chen, W., Liu, W., Geng, Y., Ohnishi, S., Sun, L., Han, W., Xu, T., Zhong, S., 2016. Life cycle based emergy analysis on China's cement production. J. Clean. Prod. 131, 272-279.

Cruz, R.V.A.D., Nascimento, C.A.O.D., 2012. Emergy analysis of oil production from microalgae.Biomass.Bioenerg. 47, 418-425.

Dincer, I., Acar, C., 2015. Review and evaluation of hydrogen production methods for better sustainability.Int. J. Hydrogen.Energ. 40, 11094-11111.

Dong, X., Ulgiati, S., Yan, M., Zhang, X., \&Gao, W., 2008. Energy and eMergy 
642

643

644

645

646

647

648

649

650

651

652

653

654

655

656

657

658

659

660

661

662

evaluation of bioethanol production from wheat in Henan Province, China.Energy Policy. 36(10), 3882-3892.

Elliott, D.C., 2013. Transportation fuels from biomass via fast pyrolysis and hydroprocessing. Wiley.Interdiscip. Rev. Energy. Environ. 2, 525-533.

Goh, C.S., Lee, K.T., 2010. Palm-based biofuel refinery (PBR) to substitute petroleum refinery: An energy and emergy assessment. Renew.Sust.Energ.Rev. 14, 2986-2995.

Han, J., Elgowainy, A., Dunn, J.B., Wang, M.Q., 2013. Life cycle analysis of fuel production from fast pyrolysis of biomass.Bioresource. Technol. 133, 421-428.

He, P., Li, S., Jin, J., Wang, H., Li, C., Wang, Y., Cui, R., 2009.Performance of an Optimized Nutrient Management System for Double-Cropped Wheat-Maize Rotations in North-Central China. Agron. J. 101, 1489.

Hu, Y., Moiwo, J.P., Yang, Y., Han, S., Yang, Y., 2010. Agricultural water-saving and sustainable groundwater management in Shijiazhuang Irrigation District, North China Plain. J.Hydrol. 393, 219-232.

Huang, J., Xiang, C., Jia, X., Hu, R., 2012.Impacts of training on farmers' nitrogen use in maize production in Shandong, China. J. Soil.Water.Conserv. 67, 321-327.

Ju, L.P., Chen, B., 2011. Embodied energy and emergy evaluation of a typical biodiesel production chain in China. Ecol. Model. 222, 2385-2392.

Kauffman, N., Hayes, D., Brown, R., 2011. A life cycle assessment of advanced biofuel production from a hectare of corn. Fuel. 90, 3306-3314.

Li, Q., Yan, J., 2012. Assessing the health of agricultural land with emergy analysis and fuzzy logic in the major grain-producing region. Catena. 99, 9-17. 
664

665

666

667

668

669

670

671

672

673

674

675

676

677

678

679

680

681

682

683

684

685

Liang, H., Ren, J., Dong, L.,Gao, Z., Zhang, N., \& Pan, M., 2016. Is the hydrogen production from biomass technology really sustainable? Answer by life cycle emergy analysis. Int. J. Hydrogen.Energ. 41(25), 10507-10514.

Liang, S., Xu, M., Zhang, T., 2013. Life cycle assessment of biodiesel production in China. Bioresource. Technol. 129, 72-77.

Liu, H.C., Yin, X.L., Wu, C.Z., 2011. Cost Analysis of Crop Residue Supplies. T Chin Soc Agric Mach, 42 (01), 106-112. (in Chinese)

Liu, X., He, P., Jin, J., Zhou, W., Sulewski, G., Phillips, S., 2011. Yield Gaps, Indigenous Nutrient Supply, and Nutrient Use Efficiency of Wheat in China. Agron. J. $103,1452$.

Lu, H., Lin, B., Campbell, D.E., Sagisaka, M., Ren, H., 2012. Biofuel vs. biodiversity? Integrated emergy and economic cost-benefit evaluation of rice-ethanol production in Japan. Energy. 46, 442-450.

Martin, J. F., Diemont, S. A., Powell, E., Stanton, M., \& Levy-Tacher, S., 2006. Emergy evaluation of the performance and sustainability of three agricultural systems with different scales and management. Agr.Ecosyst.Enviro. 115(1), 128-140.

Miao, Y., Stewart, B.A., Zhang, F., 2011. Long-term experiments for sustainable nutrient management in China.A review. Agron. Sustain. Dev. 31, 397-414.

Muradov, N., Vezirolu, T., 2005. From hydrocarbon to hydrogen? carbon to hydrogen economy. Int. J. Hydrogen.Energ. 30, 225-237.

Odum, H.T., 1988. Self-Organization, Transformity, and Information. Science 242(4882), 1132-1139. 
686

687

688

689

690

691

692

693

694

695

696

697

698

699

700

701

702

703

704

705

706

707

Odum, H.T., 1996. Environmental Accounting: Emergy and Decision Making. Wiley, New York.

Park, Y. S., Egilmez, G., \&Kucukvar, M., 2016. Emergy and end-point impact assessment of agricultural and food production in the United States: a supply chainlinked ecologically-based life cycle assessment. Ecol. Indic. 62, 117-137.

Pereira, C.L.F., Ortega, E., 2010. Sustainability assessment of large-scale ethanol production from sugarcane. J. Clean. Prod. 18, 77-82.

Ren, J., Liang, H., Dong, L., Sun, L., \&Gao, Z., 2016a. Design for sustainability of industrial symbiosis based on emergy and multi-objective particle swarm optimization. Sci. Total. Environ. 562, 789-801.

Ren, J., Manzardo, A., Mazzi, A., Fedele, A., Scipioni, A., 2013. Emergy Analysis and Sustainability Efficiency Analysis of Different Crop-Based Biodiesel in Life Cycle Perspective. The.Scientific.World. J. 2013, 1-12.

Ren, J., Tan, S., Yang, L., Goodsite, M.E., Pang, C., Dong, L., 2015a. Optimization of emergy sustainability index for biodiesel supply network design. Energ.Convers. Manage. 92, 312-321.

Ren, J., Tan, S., Goodsite, M. E., Sovacool, B. K., \& Dong, L., 2015b. Sustainability, shale gas, and energy transition in China: assessing barriers and prioritizing strategic measures. Energy.84, 551-562.

Ren, J., Xu, D., Cao, H., Wei, S. A., Dong, L., \&Goodsite, M. E., 2016b. Sustainability decision support framework for industrial system prioritization. Aiche J. 62(1), 108130. 
Saini, J.K., Saini, R., Tewari, L., 2015. Lignocellulosic agriculture wastes as biomass feedstocks for second-generation bioethanol production: concepts and recent developments. 3. Biotech. 5, 337-353.

Sims, R.E.H., Mabee, W., Saddler, J.N., Taylor, M., 2010. An overview of second generation biofuel technologies.Bioresource. Technol. 101, 1570-1580.

Spinelli, D., Jez, S., Basosi, R., 2012. Integrated Environmental Assessment of sunflower oil production. Process.Biochem. 47, 1595-1602.

Spinelli, D., Jez, S., Pogni, R., Basosi, R., 2013. Environmental and life cycle analysis of a biodiesel production line from sunflower in the Province of Siena (Italy). Energy Policy. 59, 492-506.

Sun, H., Liu, C., Zhang, X., Shen, Y., Zhang, Y., 2006. Effects of irrigation on water balance, yield and WUE of winter wheat in the North China Plain. Agr.Water. Manage. $85,211-218$.

Sun, H., Shen, Y., Yu, Q., Flerchinger, G.N., Zhang, Y., Liu, C., Zhang, X., 2010. Effect of precipitation change on water balance and WUE of the winter wheat-summer maize rotation in the North China Plain. Agr.Water. Manage. 97, 1139-1145.

Takahashi, F., Ortega, E., 2010. Assessing the sustainability of Brazilian oleaginous crops - possible raw material to produce biodiesel. Energy Policy. 38, 2446-2454.

Tao, J., Fu, M., Zheng, X., Zhang, J., Zhang, D., 2013. Provincial level-based emergy evaluation of crop production system and development modes in China.Ecol. Indic. $29,325-338$.

Wang, J.Z., 2011. Competitive advantages of shaanxi wheat corn apple and jujube based 
730

731

732

733

734

735

736

737

738

739

740

741

742

743

744

745

746

747

748 (in Chinese)

749

750

751

(in Chinese) 864-875. 173-182.

on emergy analysis [dissertation]. Yangling Shaanxi China: Northwest A \& F University.

Wang, X., Chen, Y., Sui, P., Gao, W., Qin, F., Zhang, J., Wu, X., 2014. Emergy analysis of grain production systems on large-scale farms in the North China Plain based on LCA. Agr. Syst. 128, 66-78.

Wang, X., Yang, L., Steinberger, Y., Liu, Z., Liao, S., Xie, G., 2013.Field crop residue estimate and availability for biofuel production in China. Renew. Sust. Energ. Rev. 27,

Wang, Y., Wang, E., Wang, D., Huang, S., Ma, Y., Smith, C.J., Wang, L., 2010. Crop productivity and nutrient use efficiency as affected by long-term fertilisation in North China Plain. Nutr. Cycl. Agroecosys. 86, 105-119.

Wright, M.M., Satrio, J.A., Brown, R.C., 2010. Techno-economic analysis of biomass fast pyrolysis to transportation Fuels. Technical Report: NREL/TP-6A20-46586.

Yang J, Chen B.,2014.Emergy analysis of a biogas-linked agricultural system in rural China - A case study in Gongcheng Yao Autonomous County. Applied Energy. 118(1),

Yang, H., 2011. Emergy-based evaluation research on plant bioenergy - cassava-based fuel ethanol[dissertation]. Guangzhou, China: South China University of Technology.

Yang, H., Chen, L., Yan, Z., Wang, H., 2010.Emergy analysis of cassava chips-suitable feedstock for fuel ethanol in China. Ecol. Eng. 36, 1348-1354.

Yang, Z.F., Jiang, M.M., Chen, B., Zhou, J.B., Chen, G.Q., Li, S.C., 2010. Solar emergy 
752

753

754

755

756

757

758

759

760

761

762

763

764

765

766

767

768

769

770

771

772

773

evaluation for Chinese economy. Energy Policy. 38, 875-886.

Zhang B, Chen B., 2017. Sustainability accounting of a household biogas project based on emergy. Applied Energy. 194, 819-831.

Zhang, D.Y., Ling,F.Lu., Zhang, L.F., Yang, S.Q., Liu, X.T., Gao, W.S., 2005. Emergy analysis of planting system at Congzhulingcounty in the main grain production region in Northeast China Plain. T.Chin.Sio.Agri.Eng. 21(6), 12-17. (In Chinese)

Zhang, L., Pang, M., Wang, C., 2014. Emergy analysis of a small hydropower plant in southwestern China. Ecol. Indic. 38, 81-88.

Zhang, S., Chen, X., Jia, S., Liang, A., Zhang, X., Yang, X., Wei, S., Sun, B., Huang, D., Zhou, G., 2015. The potential mechanism of long-term conservation tillage effects on maize yield in the black soil of Northeast China. Soil. Till. Res. 154, 84-90.

Zhang, X.Y., Pei, D., Hu, C.S., 2003. Conserving groundwater for irrigation in the North China Plain. Irrigation. Sci.21, 159-166.

Zhang, Y.N., Hu, G.P., Brown, R.C., 2013. Life cycle assessment of the production of hydrogen and transportation fuels from corn stover via fast pyrolysis. Environ. Res. Lett. 8 (025001), 1-13.

Zhao, B., Chen, J., Zhang, J., Xin, X., Hao, X., 2013. How different long-term fertilization strategies influence crop yield and soil properties in a maize field in the North China Plain. J. Plant.Nutr.Soil. Sc. 176, 99-109.

Zhao, Z., Qin, X., Wang, E., Carberry, P., Zhang, Y., Zhou, S., Zhang, X., Hu, C., Wang, Z., 2015. Modelling to increase the eco-efficiency of a wheat-maize double cropping system. Agr.Ecosyst.Enviro. 210, 36-46. 